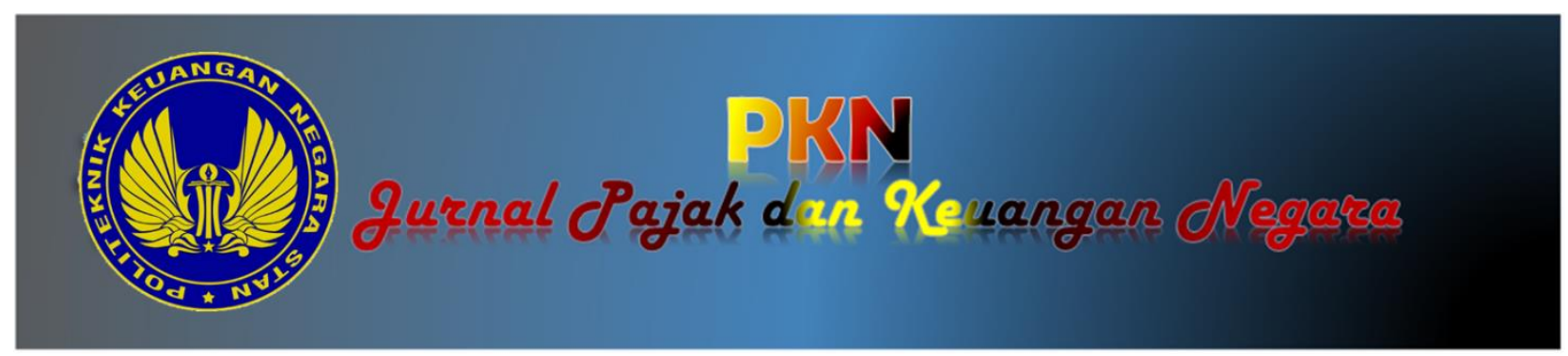

\title{
EKSISTENSI BARANG MILIK NEGARA BERUPA GEDUNG PERKANTORAN DI KAWASAN KOMERSIAL: STUDI KASUS DI KAWASAN CBD SUDIRMAN-THAMRIN JAKARTA
}

\author{
[Edy Riyanto] \\ [Prodi Penilai/PBB Jurusan Pajak PKN STAN] \\ [Budi Purnomo] \\ [Direktorat Penilaian DJKN] \\ Alamat Korespondensi: [edy.riyanto@gmail.com]
}

INFORMASI ARTIKEL

Diterima Pertama

[17 September 2019]

Dinyatakan Diterima

[28 Oktober 2019]

KATA KUNCI:

[BMN, Stakeholder, PNBP, Produktivitas]

KLASIFIKASI JEL: R520

\begin{abstract}
ABSTRAK
Property values in the Sudirman-Thamrin CBD area generally have a higher value compared to property values outside the CBD area, so the decision to build a building in the $C B D$ area needs to consider the level of productivity, especially in financial terms. The Minister of Finance as the State General Treasurer (BUN) feels it is necessary to conduct an analysis of the productivity level of government buildings in the CBD area as material for making policy on State Property in the future. In this analysis, a comparison of the level of productivity from the financial side is presented between 6 (six) government-owned office buildings and 10 (ten) private-owned office buildings. The analysis shows that the government office building from the financial side has a low level of productivity compared to private office buildings located in the Thamrin-Sudirman CBD area.
\end{abstract}

Nilai properti di kawasan CBD Sudirman-Thamrin pada umumnya memiliki nilai yang lebih tinggi dibandingkan dengan nilai properti di luar kawasan CBD, sehingga keputusan untuk membangun sebuah gedung di kawasan CBD perlu mempertimbangkan tingkat produktivitas khususnya dari segi finansial. Pemerintah yang tugas dan fungsinya untuk merumuskan kebijakan serta memberikan pelayanan terhadap stakeholder, juga memiliki gedung perkantoran yang berada di kawasan CBD Thamrin-Sudirman. Menteri Keuangan selaku Bendahara Umum Negara (BUN) merasa perlu untuk melakukan analisis terhadap tingkat produktivitas gedung pemerintah yang berada di kawasan CBD sebagai bahan pengambilan kebijakan Barang Milik Negara di kemudian hari. Dalam analisis ini, disajikan perbandingan tingkat produktivitas dari sisi finansial antara 6 (enam) gedung perkantoran milik pemerintah dengan 10 (sepuluh) gedung perkantoran milik swasta. Tingkat produktivitas diukur dari jumlah output (finansial) yang dapat dihasilkan dibagi dengan input yang dikeluarkan. Variabel output yang digunakan adalah jumlah rupiah yang dapat dihasilkan dari masing-masing gedung. Sedangkan untuk variable input yang digunakan terdiri dari tiga jenis yaitu: luas bangunan, biaya operasi, dan nilai bangunan. Hasil analisis menunjukkan bahwa gedung perkantoran pemerintahan dari sisi finansial memiliki tingkat produktivitas yang rendah dibandingkan dengan gedung perkantoran swasta yang terletak di daerah CBD Thamrin-Sudirman. 


\section{PENDAHULUAN}

\section{1 Latar Belakang}

Jalan Thamrin-Sudirman merupakan poros utama di kota Jakarta yang membujur dari utara ke selatan sejauh 8 (delapan) kilometer, merupakan daerah komersil dan menjadi jantung perekonomian Indonesia. Memiliki aset properti di kawasan komersial merupakan suatu keuntungan tersendiri di satu sisi dan memiliki tantangan untuk dapat mengelolanya dengan benar sehingga aset tersebut menjadi produktif di sisi lain. Aset produktif secara sederhana adalah aset yang mampu menghasilkan. Ataupun apabila aset tersebut tidak menghasilkan, namun di masa depan nilainya meningkat. Menghasilkan yang dimaksud di sini tentu aset yang dapat menghasilkan pendapatan bagi pemilik, atau harga aset bila dijual kembali lebih tinggi dibandingkan pada saat dahulu dibeli.

Survei produktivitas gedung di Jalan Thamrin-Sudirman diharapkan dapat memberikan informasi tentang efektivitas dalam menghasilkan output dan efisiensi penggunaan input pada properti berupa gedung yang dimiliki oleh Pemerintah Indonesia di kawasan bisnis premium, serta perbandingan produktivitasnya dengan gedung yang dimiliki dan dikelola oleh pihak swasta.

Selain itu untuk Barang Milik Negara berupa bangunan di kawasan Sudirman-Thamrin dapat dilakukan analisis komprehensif berupa tanah berikut bangunan (as improved) guna menentukan kelayakan bangunan yang sudah ada atau apakah ada alternatif jenis bangunan lain yang dapat dikembangkan di atasnya yang menghasilkan nilai tanah yang paling optimal.

\section{KERANGKA TEORI}

\subsection{Konsep Dasar Produktivitas}

Menurut Dewan Produktivitas Nasional (dalam Husien, 2002) menjelaskan bahwa Produktivitas mengandung arti sebagai perbandingan antara hasil yang dicapai (output) dengan keseluruhan sumber daya yang digunakan (input). Dengan kata lain bahwa produktivitas memliliki dua dimensi. Dimensi pertama adalah efektivitas yang mengarah kepada pencapaian target berkaitan dengan kualitas, kuantitas dan waktu, kemudian dimensi kedua yaitu efisiensi yang berkaitan dengan upaya membandingkan input dengan realisasi penggunaannya atau bagaimana pekerjaan tersebut dilaksanakan.

Dalam Integrated Management of Productivity Activities (IMPACT) framework, konsep produktivitas didefinisikan sebagai berikut:

"Productivity is not just about doing things more efficiently by "doing things right", it is also about achieving maximum effectiveness by "doing the right things".

Hal tersebut dapat disimpulkan bahwa konsep produktivitas tidak hanya mengenai melakukan sesuatu secara lebih efisien dengan melakukan hal secara benar tetapi juga mengenai pencapaian maksimum secara efektif dengan melakukan hal yang benar.

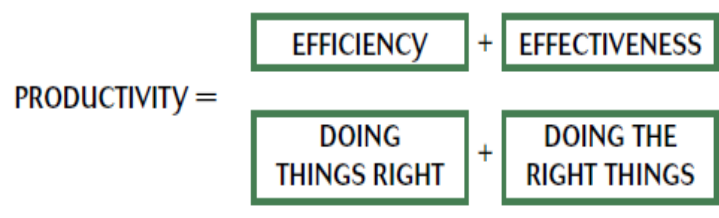

Menurut (Sarjono, 2001) terdapat 4 (empat) indikator perhitungan yang diasumsikan dapat meningkatkan produktivitas meliputi;

1. Dengan sumber daya yang lebih sedikit, diperoleh jumlah produksi yang sama.

2. Dengan sumber daya yang lebih sedikit, diperoleh hasil produksi yang lebih banyak.

3. Dengan sumber daya yang sama, diperoleh hasil produksi yang lebih banyak.

4. Dengan sumber daya yang lebih banyak, diperoleh hasil produksi yang jauh lebih banyak.

Secara teknis, produktivitas merupakan suatu perbandingan antara output dengan input. Formula produktivitas dapat dinyatakan sebagai berikut.

Produktivitas $=\frac{\text { Output }}{\text { Input }}$

Produktivitas $=\frac{\text { Efektivitas menghasilkan Output }}{\text { Efisiensi Penggunaan Input }}$

Konsep ukuran produktivitas tidak sama dengan efisiensi. Efisiensi merupakan ukuran dalam membandingkan penggunaan input yang direncanakan dengan realisasi penggunaan masukan. Apabila masukan yang sebenarnya digunakan semakin besar penghematannya maka tingkat efisiensi semakin tinggi. Namun, semakin kecil masukan yang dapat dihemat, semakin rendah tingkat efisiensi.

\subsection{Faktor-Faktor Yang Mempengaruhi Produktivitas \\ Suatu ukuran produktivitas dapat} dipengaruhi baik oleh faktor eksternal maupun faktor internal sebagai berikut:

a. Faktor Eksternal

Faktor eksternal yang dapat mempengaruhi produktivitas misalnya peraturan pemerintah, persaingan dari competitor lain, permintaan dan konsumen. Faktor-faktor eksternal tersebut di luar kontrol manajemen. Dalam beberapa kasus, faktor eksternal dapat begitu kuat 
sehingga membuat tidak berartinya langkah manajemen dalam meningkatkan produktivitas.

b. Faktor Internal

Faktor internal yang mempengaruhi produktivitas properti cenderung lebih dapat dikendalikan oleh pihak manajemen atau organisasi, antara lain:

1) Fisik Gedung seperti grade gedung, teknologi yang digunakan, tingkat keamanan gedung

2) Lokasi Gedung

3) Manajemen

4) Karyawan (tenaga kerja)

5) Kapasitas gedung dan ketersediaan space

6) Fasilitas pendukung yang ada di dalam gedung

\subsection{Pengukuran Produktivitas Barang Milik Negara} Berdasarkan Peraturan Pemerintah Nomor

27 Tahun 2014 tentang Pengelolaan Barang Milik Negara/Daerah, pengertian Barang Milik Negara (BMN) merupakan semua barang yang dibeli atau diperoleh atas beban Anggaran Pendapatan dan Belanja Negara atau berasal dari perolehan lainnya yang sah. Pengukuran produktivitas BMN dengan mengacu definisi yang dijelaskan oleh (Sarjono, 2001) dimana konsep produktivitas merupakan suatu perbandingan antara output dengan input yang dapat dikategorikan menjadi beberapa bentuk pengukuran produktivitas. Salah satunya yaitu pengukuran Produktivitas faktor tunggal (single factor productivity) yang menunjukkan produktivitas faktor tertentu yang digunakan untuk dapat menghasilkan keluaran.

Produktivitas $=\frac{\text { Output }(\text { Efektivitas })}{\text { Input }(\text { Efisiensi })}$

Untuk pengukuran produktivitas Barang Milik Negara dapat dirumuskan sebagai berikut:

$$
\begin{aligned}
\text { (1) ..........Produktivitas } & =\frac{\text { PNBP }(\text { pendapatan })}{\text { Luas Gedung }} \\
\text { (2) ..........Produktivitas } & =\frac{P N B P(\text { pendapatan })}{\text { Biaya Operasional Gedung }} \\
\text { (3) ...........Produktivitas } & =\frac{\text { PNBP }(\text { pendapatan })}{\text { Nilai Gedung }}
\end{aligned}
$$

Komponen Penerimaan Negara Bukan Pajak (PNBP) dari penggunaan maupun pemanfaatan BMN antara lain dapat berupa pendapatan sewa ruang, pendapatan sewa ATM (Anjungan Tunai Mandiri), pendapatan lain-lain yang berhubungan dengan penggunaan gedung.

\subsection{Stakeholder}

\subsubsection{Pengertian Stakeholder}

Strategic Management: A Stakeholder Approach oleh Freeman (1984) merupakan studi pertama yang mengemukakan mengenai teori stakeholder. Teori stakeholder dimulai dengan asumsi bahwa nilai secara eksplisit dan tidak dapat dipungkiri sebagai bagian dari kegiatan usaha. Teori Stakeholder menurut Ghazali dan Chariri (2007), menyatakan bahwa perusahaan bukanlah entitas yang hanya beroperasi untuk kepentingan sendiri, namun harus dapat memberikan manfaat kepada seluruh stakeholder-nya. Tujuan utama dari teori stakeholder adalah untuk membantu manajemen dalam meningkatkan penciptaan nilai sebagai dampak dari aktivitas-aktivitas yang dilakukan dan meminimalkan kerugian yang mungkin muncul bagi stakeholder.

Freeman (1984) mendefinisikan stakeholder seperti sebuah kelompok atau individual yang dapat memberi dampak atau terkena dampak oleh hasil tujuan perusahaan. Stakeholders adalah para pemangku kepentingan, yaitu pihak atau kelompok yang berkepentingan, baik langsung maupun tidak langsung, terhadap eksistensi atau aktivitas perusahaan, dan karenanya kelompok tersebut mempengaruhi dan/atau dipengaruhi oleh perusahaan.

Secara garis besar pengertian stakeholder, dapat diartikan sebagai individu atau organisasi baik profit maupun nonprofit yang memiliki kepentingan terhadap instansi/organisasi sehingga dapat mempengaruhi pencapaian tujuan perusahaan.

Reed et al (2009) mengklasifikasikan stakeholder berdasarkan "pengaruh" dan "kepentingan" sebagai berikut:

a. Subyek (Subjects) merupakan stakeholders dengan tingkat kepentingan yang tinggi tetapi memiliki pengaruh yang rendah.

b. Pemain Kunci (Key Players) merupakan stakeholders dengan tingkat kepentingan dan pengaruh yang tinggi.

c. Pengikut Lain (Crowd) merupakan stakeholders dengan tingkat kepentingan dan pengaruh yang rendah.

d. Pendukung (Contest setters) merupakan stakeholders dengan tingkat kepentingan yang rendah tetapi memiliki pengaruh yang tinggi

Menurut Nugroho (2014) stakeholder dalam program pembangunan diklasifikasikan berdasarkan peranannya, antara lain:

a. Policy creator yaitu stakeholder yang berperan sebagai pengambil keputusan dan penentu suatu kebijakan.

b. Koordinator yaitu stakeholder yang berperan mengkoordinasikan stakeholder lain yang terlibat.

c. Fasilitator yaitu stakeholder sebagai fasilitator yang berperan menfasilitasi dan mencukupi apa yang dibutuhkan kelompok sasaran. 
d. Implementer yaitu stakeholder pelaksana kebijakan yang di dalamnya termasuk kelompok sasaran.

e. Akselerator yaitu stakeholder yang berperan mempercepat dan memberikan kontribusi agar suatu program dapat berjalan sesuai sasaran atau bahkan lebih cepat waktu pencapaiannya.

\subsubsection{Analisis Stakeholder}

Para pemangku kepentingan (stakeholder) pada sebuah organisasi/instansi memiliki pengaruh yang penting bagi keberlangsungan hidup suatu organisasi/ instansi. Pengambilan sebuah kebijakan dalam penentuan keberadaan gedung-gedung milik Pemerintah di Jalan Thamrin-Sudirman juga tidak terlepas dari adanya keterkaitan dengan stakeholder. Keterlibatan stakeholder merupakan hal yang penting karena diharapkan dapat memudahkan dan mendukung pencapaian tujuan organisasi, dimana tugas dan fungsi utama berlandaskan pelayanan baik kepada masyarakat. Analisis stakeholder merupakan teknik dalam menghasilkan suatu daftar stakeholder yang akan berguna dalam pengembangan rencana pengelolaan stakeholder suatu instansi.

Berdasarkan Project Management Body Of Knowledge 5th Edition, langkah-langkah dalam Analisis Stakeholder:

a. Identifikasi Stakeholder

b. Kajian pengaruh dan kepentingan

c. Menganalisis dampak atau dukungan potensial pada masing-masing stakeholder yang dapat dikembangkan dan diklasifikasikan untuk pengembangan strategi.

d. Identifikasi partisipasi, menilai bagaimana stakeholder bereaksi atau merespon berbagai situasi dan untuk perencanaan bagaimana mempengaruhi stakeholder agar dapat meningkatkan dukungan stakeholder serta mengantisipasi dampak negatif yang mungkin muncul.

\subsection{Penggunaan Tertinggi dan Terbaik}

\subsubsection{Konsep Analisis Penggunaan Tertinggi dan Terbaik}

Dalam Kode Etik Penilai Indonesia dan Standar Penilai Indonesia 2018, PenggunaanTertinggi dan Terbaik didefinisikan sebagai penggunaan yang paling mungkin dan optimal dari suatu properti yang secara fisik dimungkinkan, telah dipertimbangkan secara memadai, secara hukum diizinkan, secara finansial layak, dan menghasilkan nilai tertinggi dari aset tersebut.

Berdasarkan Keputusan Direktur Jenderal Kekayaan Negara Nomor 184/KN.6/2013 tentang Pedoman Analisis Penggunaan Tertinggi dan Terbaik Berupa Tanah atau Tanah berikut
Bangunan. Pedoman ini merupakan acuan dalam pengelolaan aset negara yang digunakan dalam rangka pemanfaatan agar memberikan hasil yang optimal bagi negara. Sesuai dengan kepdirjen tersebut, pengertian Analisis Penggunaan Tertinggi dan Terbaik (PTT)/ Highest and Best Use (HBU) Analysis berupa Tanah atau Tanah berikut Bangunan adalah penggunaan yang paling mungkin dan optimal yang memenuhi persyaratan meliputi:

a. diizinkan secara hukum;

b. dimungkinkan secara fisik;

c. layak secara keuangan; dan

d. memberikan produktivitas tertinggi.

\subsubsection{Tujuan Analisis Penggunaan Tertinggi dan Terbaik}

Tujuan dilakukannya analisis PTT adalah untuk menentukan penggunaan yang paling layak dan optimal atas tanah atau tanah berikut bangunan dari aspek legalitas, fisik, keuangan, dan aspek produktivitas maksimal serta mendukung opini nilai. Untuk Barang Milik Negara berupa gedung-gedung di sekitar Thamrin-Sudirman dapat dilakukan analisis PTT Komprehensif berupa tanah berikut bangunan (as improved) guna menentukan kelayakan bangunan yang sudah ada atau apakah ada alternatif jenis bangunan lain yang dapat dikembangkan di atasnya yang menghasilkan nilai tanah yang paling optimal.

\subsubsection{Proses Analisis Penggunaan Tertinggi dan Terbaik}

Analisis Persyaratan Penggunaan Tertinggi dan Terbaik meliputi:

1) Analisis Aspek Legalitas

Analisis aspek legalitas adalah analisis yang dilakukan terhadap berbagai ketentuan peraturan perundang-undangan yang mempengaruhi penggunaan objek analisis. Analisis aspek legalitas meliputi analisis status dan dokumen kepemilika, analisis peruntukan area (zoning), analisis perizinan bangunan; dan/atau analisis kelayakan lingkungan berdasarkan peraturan setempat.

2) Analisis Fisik

Analisis aspek fisik adalah analisis yang dilakukan terhadap fisik tanah atau tanah berikut bangunan terkait dengan penggunaan atas tanah atau tanah berikut bangunan tersebut.

3) Analisis Keuangan

Analisis aspek keuangan adalah analisis yang dilakukan terhadap alternatif penggunaan yang memenuhi persyaratan aspek legalitas dan aspek fisik untuk mengetahui kelayakan secara keuangan atas alternatif penggunaan lahan, analisis aspek keuangan meliputi analisis 
proyeksi laba rugi dan arus kas serta analisis kelayakan proyek.

4) Analisis Maksimalisasi Produktivitas

Analisis produktivitas maksimal dilakukan untuk menentukan alternatif penggunaan yang akan memberikan nilai tanah tertinggi. Persyaratan alternatif penggunaan yang memiliki produktivitas maksimal meliputi:

a) Memiliki nilai NPV tertinggi;

b) Memiliki tingkat IRR tertinggi; dan/atau

c) Memiliki Payback Period terpendek.

\section{METODE PENELITIAN}

\subsection{Objek Barang Milik Negara}

Analisis produktivitas yang dilakukan pada Barang Milik Negara (BMN) berupa tanah dan bangunan meliputi:

1. BMN yang berlokasi di Jalan Thamrin

a. Gedung Kementerian Agama.

b. Gedung BPPT I yang digunakan BSN dan Kemenko Maritim ;

c. Gedung Bawaslu (Sekretariat Negara RI); dan

2. BMN yang berlokasi di Jalan Sudirman

a. Gedung Kantor Wilayah Direktorat Jenderal Pajak WP Besar;

b. Gedung A Kementerian Pendidikan dan kebudayaan; dan

c. Gedung Kementerian Pendayagunaan Aparatur Negara dan Reformasi Birokrasi

\subsection{Objek Gedung Swasta}

Analisis produktivitas juga dilakukan dengan metode perbandingan antara gedung milik Pemerintah dengan gedung swasta, 10 (sepuluh) gedung milik swasta tersebut meliputi:

1. Menara Thamrin

2. Gedung Jaya

3. Gedung Menara Topas

4. Wisma Nusantara

5. UOB Plaza Thamrin

6. Sampoerna Strategic North Tower

7. Gedung AIA Central

8. Gedung Plaza Asia

9. The Energy Building

10. Gedung Menara Sudirman

\subsection{Kriteria Pemilihan Objek Analisis}

\subsubsection{Objek Gedung Barang Milik Negara}

Terdapat beberapa kriteria gedung yang termasuk BMN yang dijadikan objek analisis produktivitas yaitu sebagai berikut:

a. Lokasi gedung BMN berada di Jalan Thamrin Sudirman

b. Gedung BMN "stand alone" atau bukan merupakan suatu kompleks c. Dalam hal satu kompleks terdiri dari beberapa gedung maka dipilih salah satu gedung yang mewakili.

\subsubsection{Objek Gedung Swasta}

a. Lokasi gedung berada di Jalan Sudirman Thamrin dan berdekatan dengan lokasi gedunggedung milik Pemerintah (BMN).

b. Ukuran gedung sebanding dengan gedunggedung $\mathrm{BMN}$

c. Usia gedung mewakili setiap kelompok usia gedung BMN.

d. Tersedia data yang diperlukan untuk analisis produktivitas.

3.3.3 Objek Analisis Penggunaan Tertinggi dan Terbaik

Objek gedung milik pemerintah yang dijadikan objek analisis Penggunaan Tertinggi dan Terbaik memenuhi kriteria sesuai dengan Peraturan Pemerintah Provinsi Daerah Khusus Ibukota Jakarta Nomor 1 Tahun 2014 Tentang Rencana Detail Tata Ruang Dan Peraturan Zonasi.

\subsection{Data dan Informasi}

\subsubsection{Jenis Sumber Data}

Data yang digunakan dalam analisis produktivitas ini merupakan data sekunder yang diperoleh dari Kementerian Negara/Lembaga sebagai pengguna barang dan dari hasil survei lapangan maupun dari buku literatur, peraturan perundang-undangan, studi pustaka, dan jurnal-jurnal penelitian yang meliputi:

a. Data Objek BMN

Luas bangunan, Kartu Identitas Barang (KIB), Denah Bangunan, Dokumen Legalitas seperti ljin Mendirikan Bangunan (IMB), Sertifikat Kepemilikan Tanah, Laporan Penilaian (Revaluasi BMN).

b. Data Keuangan

Pendapatan sewa, Pendapatan lain lain, Biaya pemeliharaan, Biaya service charge, Nilai Bangunan.

c. Data Pendukung

Grade dan kelas bangunan BMN, Fasilitas yang tersedia di gedung BMN, Objek pemanfaatan dan profile satker yang ada dalam form di SIMAN, Tingkat Hunian, Rencana umum tata ruang.

\subsection{Survei Lapangan}

Survei lapangan produktivitas gedung milik pemerintah dibandingkan dengan gedung milik swasta di Jalan Thamrin-Sudirman, Jakarta dilakukan di semester I tahun 2018.

\subsection{Teknik Analisis}

Meliputi:

1. Pengumpulan data dan informasi yang relevan dengan pelaksanaan survei produktivitas;

2. Menganalisis data dan informasi untuk pelaksanaan analisis hasil survei; 
3. Melakukan validasi nilai BMN pada aplikasi http://sipreval.kemenkeu.go.id;

4. Analisis produktivitas dengan menggunakan metode perbandingan gedung milik swasta dengan gedung milik pemerintah;

5. Analisis Stakeholder;

6. Analisis Penggunaan Tertinggi dan Terbaik/ Highest And Best Use.

\section{HASIL PENELITIAN}

\subsection{Data Gedung Objek Survei}

4.1.1 Gedung BMN

a. Gedung Kementerian Agama

1) Deskripsi

Gedung Kementerian Agama berlokasi di Jalan Thamrin No.6 Jakarta Pusat. Sesuai dengan KIB, Gedung Kementerian Agama terdiri dari 2 gedung utama yakni: Gedung Utama I dengan luas $6.696 \mathrm{~m}^{2}$ berdiri diatas tanah seluas $624 \mathrm{~m}^{2}$. Gedung Utama II dengan luas sebesar $35.268 \mathrm{~m}^{2}$ yang terdiri dari 20 lantai, merupakan gedung terbaru yang dibangun pada tahun 2009 sesuai IMB nomor 2287/IMB/2009 tanggal 20 Maret 2009. Jumlah pegawai di Kementerian Agama berkisar 1500 pegawai.

2) Biaya Pengelolaan Gedung

Biaya-biaya yang dikeluarkan oleh DIPA Kementerian Agama pada tahun 2017 meliputi:

\begin{tabular}{lr}
\multicolumn{1}{c}{ Uraian } & \multicolumn{1}{c}{ Biaya (Rp) } \\
Biaya Listrik & $3.404 .023 .146,00$ \\
Biaya Air & $198.667 .560,00$ \\
Biaya Telepon & $59.203 .998,00$ \\
Biaya Kebersihan/Perawatan & \\
Gedung & $2.308 .482 .000,00$
\end{tabular}

\section{b. Gedung Badan Pengkajian dan Penerapan Teknologi I (BSN/ Kemenko Maritim)}

1) Deskripsi Lokasi

Gedung Badan Pengkajian dan Penerapan

Teknologi I (BPPT I) ini berlokasi di Jalan M.H. Thamrin No. 8, Kebon Sirih, Kec. Menteng, RT.2/RW.1, Kebon Sirih, Menteng, Jakarta Pusat. Gedung BPPT I saat ini dipergunakan oleh 2 (dua) Kementerian/Lembaga yakni Kementerian Koordinator Bidang Kemaritiman RI (Kemenko Maritim) dan Badan Standardisasi Nasional (BSN).

2) Biaya Pengelolaan Gedung dan PNBP

a) Badan Standardisasi Nasional (BSN)

Biaya-biaya yang dikeluarkan oleh DIPA BSN pada tahun 2017 meliputi:

\begin{tabular}{|c|c|}
\hline Uraian & Biaya (Rp) \\
\hline Biaya Pemeliharaan Gedung & $500.000 .000,00$ \\
\hline
\end{tabular}

Biaya Keamanan,

Kebersihan Dan Pegawai

$3.100 .000 .000,00$

Honorer Secara Swakelola

Biaya lain berupa biaya listrik dan telepon dibebankan pada anggaran Kemenko Maritim.

b) Kemenko Maritim

Biaya-biaya yang dikeluarkan oleh DIPA Kemenko Maritim meliputi:

\begin{tabular}{lcc}
\multicolumn{1}{c}{ Uraian } & Biaya (Rp) & Keterangan \\
\hline Biaya Listrik & $496.689 .225,00$ & Januari-Februari 2018 \\
Biaya Telepon & $20.663 .785,00$ & Februari-Maret 2018 \\
$\begin{array}{l}\text { Biaya } \\
\begin{array}{l}\text { Pemeliharaan } \\
\text { Gedung }\end{array}\end{array}$ & $158.018 .500,00$ & Januari-Maret 2018 \\
\end{tabular}

c. Gedung Bawaslu (milik Sekretariat Negara RI)

1) Deskripsi Lokasi

Gedung Bawaslu berlokasi di Jalan M.H. Thamrin No.14, Gondangdia, Menteng, RT.8/RW.4, Gondangdia, Menteng, Jakarta Pusat. Sesuai dengan KIB, gedung ini memiliki luas $4.890 \mathrm{~m}^{2}$ yang terdiri dari 5 (lima) lantai typical sehingga dapat diperkirakan keluasan per lantai sebesar $978 \mathrm{~m}^{2}$. Total jumlah pegawai di Bawaslu ini adalah 434 orang.

2) Biaya Pengelolaan Gedung

Biaya-biaya yang dikeluarkan oleh DIPA Bawaslu pada tahun 2017 meliputi:

\begin{tabular}{lc}
\multicolumn{1}{c}{ Uraian } & Biaya (Rp) \\
\hline Biaya Pemeliharaan Peralatan dan Mesin & $532.996 .812,00$ \\
Biaya Belanja Jasa Lainnya & $806.244 .410,00$ \\
Biaya Listrik & $1.424 .230 .816,00$ \\
$\begin{array}{l}\text { Biaya Pemeliharaan Gedung dan } \\
\text { Bangunan }\end{array}$ & $694.121 .996,00$
\end{tabular}

d. Gedung Kanwil Direktorat Jenderal Pajak Wajib Pajak Besar

1) Deskripsi Lokasi

Gedung Kanwil DJP WP Besar berlokasi di Jl. Jend. Sudirman Kav. 56, RT.5/RW.3, Senayan, Kby. Baru, Jakarta Selatan. Gedung Kanwil DJP WP Besar ini memiliki luas sebesar $19.776 \mathrm{~m}^{2}$ yang terdiri dari 21 lantai.

2) Biaya Pengelolaan Gedung

Biaya-biaya yang dikeluarkan oleh DIPA Kanwil DJP WP Besar tahun 2017 meliputi:

\begin{tabular}{cl}
\hline Uraian & Biaya (Rp) \\
\hline Biaya Utilitas Gedung & $5.706 .892 .896,00$
\end{tabular}

e. Gedung A Kementerian Pendidikan dan Kebudayaan

1) Deskripsi Lokasi 
Gedung A Kementerian Pendidikan dan Kebudayaan (Kemendikbud) berlokasi di Jl. Jenderal Sudirman, Senayan, Jakarta Selatan. Komplek gedung Kemendikbud terdiri dari 7unit dengan keluasan untuk GedungA (4 lantai) $19.088 \mathrm{~m}^{2}$, Gedung B (7 lantai) $12.717 \mathrm{~m}^{2}$, Gedung C (20 lantai) $34.000 \mathrm{~m}^{2}$, Gedung D (18 lantai) $9.500 \mathrm{~m}^{2}$, Gedung E (19 lantai) $41.840 \mathrm{~m}^{2}$, Gedung F (6 lantai) 11.391 $\mathrm{m}^{2}$, Gedung Kemendikbud ini digunakan oleh 6.554 orang pegawai.

2) Biaya Pengelolaan Gedung dan PNBP

Biaya-biaya yang dikeluarkan oleh DIPA Kemendikbud pada tahun 2017 meliputi:

\begin{tabular}{lrc}
\multicolumn{1}{c}{ Uraian } & \multicolumn{1}{c}{ Biaya (Rp) } & Keterangan \\
& 5.684 .456 .500 & Gedung A \\
Biaya & 10.709 .676 .000 & Gedung C \\
Pemeliharaan & 1.076 .218 .000 & Gedung F \\
& 7.643 .920 .324 & Gedung A, C dan F \\
Biaya Utilitas & 1.242 .324 .805 & Gedung B \\
Biaya Listrik & 55.590 .053 & Gedung B \\
Biaya Telepon & 302.204 .440 & Gedung B \\
Biaya Air &
\end{tabular}

Dalam lokasi kantor terdapat ruang yang disewakan sebagai Kantor Bank, Ruang ATM, BTS, dan Kantin. Untuk analisis ini akan dipilih salah satu gedung yaitu gedung $\mathrm{A}$ untuk diperbandingkan tingkat penerimaan dan biaya yang dikeluarkannya. Adapun untuk besaran penerimaan yang dihasilkan oleh Gedung A selama tahun 2017 adalah sebesar Rp727.857.289,00.

\section{f. Gedung Kementerian Pendayagunaan Aparatur Negara dan Reformasi Birokrasi}

1) Deskripsi Lokasi

Gedung Kementerian Pendayagunaan Aparatur Negara dan Reformasi Birokrasi (KemenPAN RB) berlokasi di Jl. Jenderal Sudirman Kav. 69, RT.8/RW.2, Senayan, Kebayoran Baru, RT.8/RW.2, Senayan, Kebayoran Baru, Jakarta Selatan. Gedung KemenPAN RB ini memiliki keluasan sebagai berikut:

- Luas Gedung Utama NUP $1=5.278 \mathrm{~m}^{2}$

Luas Gedung Utama NUP $2=2.597 \mathrm{~m}^{2}$

- Luas Gedung Kantin NUP $3=54 \mathrm{~m}^{2}$

Gedung KemenPAN RB ini digunakan oleh 563 orang pegawai. Secara umum apabila dilihat dari rasio keluasan dengan jumlah pegawai, keluasan gedung sudah cukup mendukung kenyamanan kerja pegawai.

2) Biaya Pengelolaan Gedung dan PNBP

Biaya-biaya yang dikeluarkan oleh DIPA KemenPAN RB meliputi:

Uraian Biaya (Rp)

Keterangan

$\begin{array}{llr}\text { Biaya Pemeliharaan } & 2.626 .635 .000,00 & \text { Tahun } 2017 \\ \text { Biaya Utilitas } & 1.882 .033 .321,00 & \text { Tahun } 2017 \\ \text { Biaya Pemeliharaan } & 2.797 .062 .000,00 & \text { Tahun } 2018\end{array}$

Dalam kompleks kantor KemenPAN RB, terdapat ruang yang disewakan sebagai ATM. Hal ini menjadi penerimaan bagi Negara dalam bentuk PNBP dengan besaran sebagai berikut:

\begin{tabular}{|cr|}
\hline Uraian & \multicolumn{1}{c}{ Jumlah $(\mathbf{R p})$} \\
\hline PNBP tahun 2016 & $114.194 .851,00$ \\
PNBP tahun 2017 & $74.177 .000,00$
\end{tabular}

\subsubsection{Gedung Swasta}

Dalam analisis produktivitas ini, terdapat 10 (sepuluh) gedung perkantoran swasta yang akan dibandingkan dengan gedung kantor pemerintahan di sepanjang Jalan Thamrin-Sudirman. Dari pengamatan singkat survei secara umum, grading gedung perkantoran swasta di sepanjang Jalan Thamrin berada pada grade $\mathrm{B}$, sementara gedung perkantoran swasta di sepanjang Jalan Sudirman berada pada grade $A$. Hal ini kemungkinan banyak dipengaruhi oleh preferensi penyewa yang lebih banyak ke gedung perkantoran swasta sepanjang Jalan Sudirman serta adanya Sudirman Central Business District (SCBD) di Jalan Sudirman. Selain itu, dipengaruhi juga oleh fasilitas pendukung maupun mitra bisnis yang ada di daerah tersebut.

Tarif sewa setiap gedung perkantoran swasta di sepanjang Jalan Thamrin-Sudirman cukup bervariasi. Begitu pula halnya dengan tarif sewa dalam gedung yang sama, hal ini dapat dipengaruhi oleh grade gedung, fasilitas yang tersedia, kelengkapan peralatan di dalam kantor (furnished/unfurnished), posisi lantai gedung, serta faktor terkait lainnya.

Asking Base Rents, Service Charges \& Occupancy

\begin{tabular}{lcc}
\multicolumn{1}{c}{ Thamrin } & $\mathbf{2 0 1 7}$ & $\mathbf{2 0 1 8}$ YTD \\
$\begin{array}{l}\text { Base Rents (IDR/sq } \\
\text { m/month) }\end{array}$ & 291,535 & 275,499 \\
$\begin{array}{l}\text { Service Charges } \\
\text { (IDR/sq m/month) }\end{array}$ & 91,818 & 92,589
\end{tabular}

Occupancy (\%) 91.6

\begin{tabular}{lcc}
\multicolumn{1}{c}{ Sudirman } & $\mathbf{2 0 1 7}$ & $\mathbf{2 0 1 8}$ YTD \\
\hline $\begin{array}{l}\text { Base Rents (IDR/sq } \\
\text { m/month) }\end{array}$ & 310,964 & 355,228 \\
$\begin{array}{l}\text { Service Charges } \\
\text { (IDR/sq m/month) }\end{array}$ & 85,117 & 82,399 \\
Occupancy (\%) & 85.3 & 80.0
\end{tabular}


Sumber : Colliers (2018)

\section{a. Menara Thamrin}

Gedung Menara Thamrin berlokasi di Jl. M.H. Thamrin No. Kav 3, Kb. Sirih, menteng, Jakarta Pusat. Gedung menara thamrin ini termasuk dalam kategori gedung grade $\mathrm{B}$. Tarif sewa ruangan di gedung ini berkisar pada $\mathrm{Rp} 250.000,00 / \mathrm{m}^{2} /$ bulan dengan service charge sebesar Rp95.000,00.

\section{b. Gedung Jaya}

Gedung Jaya berlokasi di Jl. M.H. Thamrin No.12 Jakarta Pusat, dalam kaitannya dengan kategori gedung, gedung Jaya ini termasuk dalam kategori gedung grade $\mathrm{B}$. Tarif sewa ruangan di gedung ini dimulai pada $\mathrm{Rp} 200.000,00 / \mathrm{m}^{2} /$ bulan dengan service charge sebesar Rp95.000,00.

\section{c. Gedung Menara Topas}

Gedung Menara Topas berlokasi di J. M.H. Thamrin No.9 Jakarta Pusat, gedung Menara Topas ini termasuk dalam kategori gedung grade $\mathrm{B}$. Tarif sewa ruangan di gedung ini dimulai pada Rp170.000,00/ $\mathrm{m}^{2} /$ bulan dengan service charge sebesar Rp90.000,00.

\section{d. Wisma Nusantara}

Gedung Wisma Nusantara berlokasi di Jl. M.H. Thamrin No. 59 Jakarta, gedung ini termasuk dalam kategori gedung grade B. Tarif sewa ruangan di gedung ini berkisar pada Rp250.000,00$\mathrm{Rp} 440.000,00 / \mathrm{m}^{2} /$ bulan dengan service charge sebesar Rp110.000,00.

\section{e. UOB Plaza Thamrin}

Gedung UOB Plaza Thamrin berlokasi di Jalan M.H. Thamrin Kav 8-10, Tanah Abang, RT.14/RW.20, Kebon Melati, Jakarta Pusat. Tarif sewa ruangan di gedung ini berkisar pada Rp275.000,00/ $\mathrm{m}^{2} /$ bulan dengan biaya service charge Rp90.000,00/m²/bulan.

\section{f. Sampoerna Strategic North Tower}

Gedung Sampoerna Strategic North Tower berlokasi di Jl. Jenderal Sudirman Kav 45 Jakarta Selatan, gedung Sampoerna Strategic North Tower ini termasuk dalam kategori gedung grade A. Tarif sewa ruangan di gedung ini dimulai pada Rp295.000,00/ $\mathrm{m}^{2} /$ bulan denganservice charge sebesar Rp90.000,00.

\section{g. Gedung AIA Central}

Gedung AIA Central berlokasi di Jl. Jenderal Sudirman Kav. 48A, Karet Semanggi, Setia Budi, Jakarta Selatan, gedung AIA Central ini termasuk dalam kategori gedung grade $A$. Tarif sewa ruangan di gedung ini dimulai pada Rp275.000,00/ $\mathrm{m}^{2} /$ bulan dengan service charge sebesar Rp55.000,00.

\section{h. Gedung Plaza Asia}

Gedung Plaza Asia berlokasi di Jl. Jenderal Sudirman Kav. 59, Jakarta Selatan, gedung Plaza Asia ini termasuk dalam kategori gedung grade $B$.
Tarif sewa ruangan di gedung ini dimulai dari $\mathrm{Rp} 300.000,00 / \mathrm{m}^{2} /$ bulan dengan service charge sebesar Rp35.000,00.

\section{i. The Energy Building}

Gedung The Energy Building berlokasi di Jl. Jend Sudirman Kav 52 - 53 Lot 11A SCBD, Kota Jakarta Selatan, Gedung ini termasuk dalam kategori gedung grade A. Tarif sewa ruangan di gedung ini dimulai pada $\mathrm{Rp} 440.000,00 / \mathrm{m}^{2} /$ bulan dengan service charge sebesar Rp55.000,00.

\section{j. Gedung Menara Sudirman}

Gedung Menara Sudirman berlokasi di Jl. Jenderal Sudirman Kav 60, Kota Jakarta Selatan. Gedung ini termasuk dalam kategori gedung grade B. Gedung Menara Sudirman ini memiliki akses menuju Sudirman Central Business District (SCBD). Tarif sewa ruangan di gedung ini dimulai pada Rp275.000,00/ $\mathrm{m}^{2} /$ bulan dengan service charge sebesar Rp66.000,00.

\subsection{Analisis Produktivitas}

\subsubsection{Tingkat Produktivitas Gedung Pemerintah}

Bangunan gedung pemerintah pada dasarnya dibangun untuk menunjang tugas dan fungsi pemerintah sebagai penyusun kebijakan dan pelayan publik. Dengan demikian untuk melakukan pengukuran tingkat produktivitas gedung pemerintahan secara finansial, dapat didekati dengan data jumlah Penerimaan Negara Bukan Pajak (PNBP) yang dihasilkan. Selanjutnya dalam analisis ini diperhitungkan menggunakan formula sebagai berikut:

$$
\begin{aligned}
& \text { (1) ..........Produktivitas }=\frac{\text { PNBP (pendapatan })}{\text { Luas Bangunan }} \\
& \text { (2) ..........Produktivitas }=\frac{\text { PNBP (pendapatan })}{\text { Biaya Pemeliharaan } / \text { Service Charge }} \\
& \text { (3) ...........Produktivitas }=\frac{\text { PNBP (pendapatan })}{\text { Nilai Bangunan }}
\end{aligned}
$$

Berikut disajikan data PNBP yang dapat dihasilkan oleh 6 (enam) gedung pemerintahan yang terletak di ruas Jalan Thamrin - Sudirman.

\begin{tabular}{|c|l|r|r|}
\hline \multirow{2}{*}{ No } & \multicolumn{1}{|c|}{ Gedung } & Total Luas $\left(\mathrm{m}^{2}\right)$ & PNBP $(\mathrm{Rp})$ \\
\hline 1 & Kemenag & 35.268 & $\cdot$ \\
\hline 2 & BSNKemenko Maritim & 74.414 & $\cdot$ \\
\hline 3 & Bawaslu & 4.890 & $\cdot$ \\
\hline 4 & Kanwil DJP WP Besar & 19.776 & $\cdot$ \\
\hline 5 & Kemendikbud Ged A & 19.088 & 727.857 .289 \\
\hline 6 & KemenPANRB & 7.929 & 74.177 .000 \\
\hline \multicolumn{2}{|c|}{ PNBP yang dihasilkan oleh gedung } \\
\hline
\end{tabular}
pemerintahan pada dasarnya merupakan hasil pemanfaatan atas sebagian ruangan gedung yang tidak digunakan untuk pelaksanaan tugas dan fungsi oleh pihak ketiga. 
Berdasarkan data tersebut di atas dapat dihitung tingkat produktivitas gedung pemerintah dengan formula (1) dengan hasil sebagai berikut:

\begin{tabular}{|c|c|c|c|}
\hline Gedung & Total Las (m:) & PNBP $($ RP $)$ & $\begin{array}{c}\text { PNBP } \\
\text { Luas Gedung }\end{array}$ \\
\hline 1 Kenenena & 35.680 & & \\
\hline 2 BSWKKementho Wartín & 74.414 & . & . \\
\hline 3 Bawnasu & 4.890 & & \\
\hline 4 Kanwi D.JPWP Besara & 19.776 & . & . \\
\hline 5 Kemenordkoud Geed A & 190.080 & 727.857 .289 & 381.132 \\
\hline \begin{tabular}{l|l|}
6 KemennPANB \\
\end{tabular} & 7.929 & $74,177.000$ & 9.355 \\
\hline
\end{tabular}

Data berikut menunjukkan hasil survei atas besaran yield yang dapat dihasilkan oleh gedung pemerintahan

\begin{tabular}{|c|c|c|c|}
\hline Ceedung & Pelkiriaan Nilab Bangynanan & PNBP $($ RP $)$ & Yield \\
\hline 1 Kemenenge & 2728.801 .1355000 & & 0,00 \\
\hline 2 BSWKemento Waritim & 451.026.9899000 & & 0,000 \\
\hline 3 Bawaslu & 355800.563 .000 & & 0,00 \\
\hline 4 Kanuil D.JPWP Besara & 157.5048880 .000 & & 0,0 \\
\hline 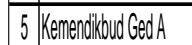 & 251.04 .372000 & 727.857 .889 & 0.2 \\
\hline \begin{tabular}{|l|l|}
6 & KenenPPANRB \\
\end{tabular} & 568824.907 .00 & $74.177,000$ & 0 \\
\hline
\end{tabular}

Data tersebut di atas menunjukkan bahwa yield yang dapat dihasilkan dari gedung pemerintahan melalui pemanfaatan sebagian ruangan/gedung sangat rendah. Begitu juga halnya ketika pendapatan gedung pemerintah dibandingkan dengan biaya operasi, maka pada dasarnya akan menghasilkan angka negatif yaitu besaran biaya yang dikeluarkan lebih besar dari pendapatan yang diperoleh.

\begin{tabular}{|c|c|c|c|c|}
\hline Gedung & PNBP $\left(R_{P}\right)$ & $\begin{array}{c}\text { Total Biaya } \\
\text { Operasional (Rpo) }\end{array}$ & PNBP · Biaja & PNBPB Biaya \\
\hline 1 Kemeneag & . & 3.661.894.704 & $(3.661 .894 .704)$ & 0,00 \\
\hline 2 BSW Kenentko Naritim & . & 3.100 .000 .000 & $(3,100,000,000)$ & 0,00 \\
\hline 3 Bawasulu & . & 2230.475 .226 & $(2230.475 .226)$ & 0,00 \\
\hline 4 |Kanwi D.JP WP Besar & . & 5.706 .8928 .996 & $(5,706.9998 .996)$ & 0,00 \\
\hline 5 Kemendikoud Ged A & 727.857 .289 & 2.547 .973 .441 & $(1.820,116,152$ & 0,29 \\
\hline $6 \mid$ KemenPANRB & 74.177 .000 & 1.88202033.321 & $\mid(1.807 .856 .321)$ & 0,04 \\
\hline
\end{tabular}

Selanjutnya disajikan perhitungan tingkat produktivitas gedung pemerintah dengan berbagai variabel

\begin{tabular}{|c|c|c|c|c|}
\hline No & Gedung & $\begin{array}{c}\text { Pendapatan/ } \\
\text { m2tahun }\end{array}$ & $\begin{array}{c}\text { Pendapatan Total } \\
\text { Biaya }\end{array}$ & $\begin{array}{c}\text { Pendapatan Nilai } \\
\text { Bangunan }\end{array}$ \\
\hline \multicolumn{2}{|c|}{1 Kemenag } & . & & $0,00 \%$ \\
\hline \multicolumn{2}{|c|}{2 BSNKKemenko Maritim } & . & & $0,00 \%$ \\
\hline \multicolumn{2}{|c|}{\begin{tabular}{l|l}
3 & Bawaslu \\
\end{tabular}} & . & & $0,00 \%$ \\
\hline \multicolumn{2}{|c|}{4 Kanwil DJPWP Besar } & . & & $0,00 \%$ \\
\hline \multicolumn{2}{|c|}{5 Kemendikbuud Ged A } & 38.132 & 0,29 & $0,29 \%$ \\
\hline \multicolumn{2}{|c|}{6 KemenPANRB } & 9.355 & 0,04 & $0,13 \%$ \\
\hline \multicolumn{2}{|c|}{ Rata-rata } & 7.914 & & $0,00 \%$ \\
\hline
\end{tabular}

\subsubsection{Tingkat Produktivitas Gedung Swasta}

Bangunan gedung komersial milik swasta dibangun dengan tujuan untuk mendapatkan income dari penyewaan ruangan. Keputusan dalam pembangunan sebuah gedung dengan tujuan komersial akan didahului dengan analisis kelayakan investasi, sehingga indikator-indikator kelayakan finansial dapat dijadikan ukuran dalam mengukur tingkat produktivitas bangunan.

Berikut disajikan kembali data 10 gedung swasta yang menjadi objek analisis:

\begin{tabular}{|c|c|c|c|c|c|}
\hline Gedung & Tahun dibangun & Grade & Luas (m2) & Base Rentm2 & Service Charge/m2 \\
\hline | Menara Thamrin & 1991 & $B$ & 35.102 & 250.000 & 95.000 \\
\hline 2 Geduno Jaya & 1974 & $B$ & 10.508 & 200.000 & 95.000 \\
\hline 3 Menara Topas & 1990 & B & 13.478 & 170.000 & 90.000 \\
\hline 4 |Wisma Nusantara & 1972 & $B$ & 25.380 & 3000000 & 110.000 \\
\hline 5 UOB Plaza Thamin & 2009 & $B$ & 76.030 & 275.000 & 90.000 \\
\hline 6 Sampoerna Strategic North Tower & 2008 & A & 37.484 & 295.000 & 90.000 \\
\hline 7 Gedung AlA Centrial & 2015 & $A$ & 47,000 & 275.000 & 55.000 \\
\hline 8 Gedung Plaza Asia & 2005 & $B$ & 26.203 & 280.000 & 30.000 \\
\hline \begin{tabular}{l|l|} 
9 The Energy Building \\
\end{tabular} & 2008 & A & 65.774 & 440.000 & 55.000 \\
\hline 10|Menara Sudirman & 1995 & B & 19.881 & 275.000 & 66.000 \\
\hline
\end{tabular}

Dengan menggunakan data tersebut di atas, dilakukan simulasi perhitungan untuk memperkirakan tingkat produktivitas gedung. Tingkat produktivitas gedung dihitung dengan mengukur besaran yield yang dapat dihasilkan dari gedung tersebut.

Dalam analisis ini, untuk memperkirakan besaran pendapatan per tahun mempertimbangkan besaran asking base rent, service charge, lettable area, dan rata-rata tingkat okupansi. Besaran asking base rent dan service charge dapat diperoleh dari property manager gedung yang bersangkutan. Keluasan yang dapat disewakan (lettable area) diperhitungkan dengan mempertimbangkan proporsi keluasan rata-rata dari luas gedung ( gross) yaitu sebesar $88 \%$ dari total luas gedung (gross). Sedangkan untuk memperkirakan tingkat okupansi gedung, analisis ini menggunakan data yang diterbitkan oleh Colliers International dalam jurnal yang berjudul "Jakarta Property Market Report Q1 2018". Tingkat okupansi rata-rata gedung perkantoran untuk kawasan Sudirman berkisar antara $80 \%-85 \%$ dan untuk kawasan Thamrin $\pm 90 \%$.

Berdasarkan data-data tersebut dapat diperkirakan besaran pendapatan per tahun pada gedung perkantoran milik swasta adalah sebagai berikut:

\begin{tabular}{|c|c|c|c|c|c|}
\hline Gedung & $\begin{array}{l}\text { Luas Semi } \\
\text { Gross } \\
\text { (m2) }\end{array}$ & Occup, Rate & $\begin{array}{l}\text { Base Rentmm2 } \\
\quad(\mathbb{R} p)\end{array}$ & $\begin{array}{c}\text { Service } \\
\text { Chargeim2 } \\
(\mathrm{RP})\end{array}$ & $\begin{array}{l}\text { Pendapatan / tahun } \\
\qquad(\mathbb{R} p)\end{array}$ \\
\hline 1|Menara Thamin & 30.890 & $90 \%$ & 250.000 & 95.000 & 90.900 .223 .445 \\
\hline 2 Gedung Jaya & 9.247 & $90 \%$ & 200.000 & 95.000 & 21.968 .470 .339 \\
\hline 3 Menara Topas & 11.861 & $90 \%$ & 170.000 & 90.000 & 24.075 .438 .710 \\
\hline 4 Wisma Nusanntara & 22.340 & $90 \%$ & 300.000 & 110.000 & 78.786 .243 .043 \\
\hline 5 UOB Plaza Thamin & 66.906 & $90 \%$ & 275.000 & 90.000 & 215.476 .075 .584 \\
\hline 6 Sampoerna Strategic North Tower & 32.986 & $80 \%$ & 295.000 & 90.000 & 101.079 .414 .374 \\
\hline 7 Gedung AIA Central & 41.300 & $80 \%$ & 275.000 & 55.000 & 116.942 .918 .400 \\
\hline 8Gedung Plaza Asia & 23.059 & $80 \%$ & 280.000 & 30.000 & 65.777998 .810 \\
\hline 9 The Energy Building & 57.881 & $80 \%$ & 440.000 & 55.000 & 259.923 .272 .717 \\
\hline 10 Menara Sudirman & 17.495 & $80 \%$ & 275.000 & 66.000 & 49.660.842.148 \\
\hline
\end{tabular}


Besaran pendapatan per tahun tersebut menjadi output yang akan digunakan dalam menghitung tingkat produktivitas gedung.

Selanjutnya, sebagai besaran nilai input, analisis ini menggunakan 3 variabel yaitu, luas bangunan, nilai bangunan, dan biaya operasi/pemeliharaan. Luas bangunan yang digunakan adalah luas bangunan gross. Nilai Bangunan diperoleh dengan memperkirakan besaran biaya pembangunan baru dikurangi dengan penyusutan. Biaya operasi dihitung berdasarkan besaran service charge yang dikenakan.

Berikut disajikan data variabel input:

\begin{tabular}{|c|c|c|c|}
\hline Gedung & Luas (m2) & Nilai Bangunan & Total Biaya Operasi \\
\hline 1|Menara Thamrin & 35.102 & 313.004 .534 .000 & 40.016 .280 .000 \\
\hline 2 Gedung Jaya & 10.508 & 93.699 .836 .000 & 11.979 .120 .000 \\
\hline 3/Menara Topas & 13.478 & 120.183 .326 .000 & 14.556 .240 .000 \\
\hline 4 Wisma Nusantara & 25.386 & 226.366 .962 .000 & 33.509 .520 .000 \\
\hline $5 \mid$ UOB Plaza Thamin & 76.030 & 677.959 .510 .000 & 82.112 .400 .000 \\
\hline $6 \mid$ Sampoerna Strategic North Tower & 37.484 & 492.764 .664 .000 & 40.482 .720 .000 \\
\hline 7 Gedung AlA Central & 47.000 & 617.862 .000 .000 & 31.020 .000 .000 \\
\hline \begin{tabular}{|l|l|l|} 
Gedung Plaza Asia \\
\end{tabular} & 26.203 & 233.652 .151 .000 & 9.433 .080 .000 \\
\hline \begin{tabular}{l|l|l|l|l} 
The Energy Building \\
\end{tabular} & 65.774 & 864.665 .004 .000 & 43.410 .840 .000 \\
\hline 10|Menara Sudirman & 19.881 & 261.355 .626 .000 & 15.745 .752 .000 \\
\hline
\end{tabular}

produktivitas dengan berbagai variabel

\begin{tabular}{|c|l|r|c|c|}
\hline No & \multicolumn{1}{|c|}{ Gedung } & Pendapatan/ m2 & $\begin{array}{c}\text { Pendapatan/ Total } \\
\text { Biaya }\end{array}$ & $\begin{array}{c}\text { Pendapatan/ Nilai } \\
\text { Bangunan }\end{array}$ \\
\hline \hline 1 & Menara Thamrin & 2.589 .602 & 2,3 & $29 \%$ \\
\hline 2 & Gedung Jaya & 2.090 .642 & 1,8 & $23 \%$ \\
\hline 3 & Menara Topas & 1.786 .277 & 1,7 & $20 \%$ \\
\hline 4 & Wisma Nusantara & 3.103 .531 & 2,4 & $35 \%$ \\
\hline 5 & UOB Plaza Thamrin & 2.834 .093 & 2,6 & $32 \%$ \\
\hline 6 & Sampoerna Strategic North Tower & 2.696 .602 & 2,5 & $21 \%$ \\
\hline 7 & Gedung AlA Central & 2.488 .147 & 3,8 & $19 \%$ \\
\hline 8 & Gedung Plaza Asia & 2.510 .323 & 7,0 & $28 \%$ \\
\hline 9 & The Energy Building & 3.951 .763 & 6,0 & $30 \%$ \\
\hline 10 & Menara Sudirman & 2.497 .905 & 3,2 & $19 \%$ \\
\hline & Rata-rata & 2.654 .889 & 3,3 & $26 \%$ \\
\hline
\end{tabular}

Berdasarkan data tersebut dapat diketahui bahwa rata-rata pendapatan $/ \mathrm{m}^{2}$ yang dapat dihasilkan oleh gedung perkantoran swasta di ruas Jalan Thamrin-Sudirman adalah sebesar \pm Rp2.650.000 per $\mathrm{m}^{2}$ pertahun. Dari sudut pandang produktivitas penggunaan biaya dapat diperoleh rasio rata-rata pendapatan terhadap beban operasi adalah sebesar 3,3. Angka tersebut dapat diartikan bahwa setiap penggunaan biaya operasi Rp1 dapat menghasilkan Rp3,3. Sedangkan produktivitas bangunan gedung dari sisi investasi dapat menghasilkan yield/return sebesar $26 \%$ per tahun.

\subsubsection{Perbandingan Tingkat Produktivitas Gedung Pemerintah dengan Gedung Swasta}

Pada tabel berikut di bawah ini disajikan indikator tingkat produktivitas gedung dari sisi finansial.

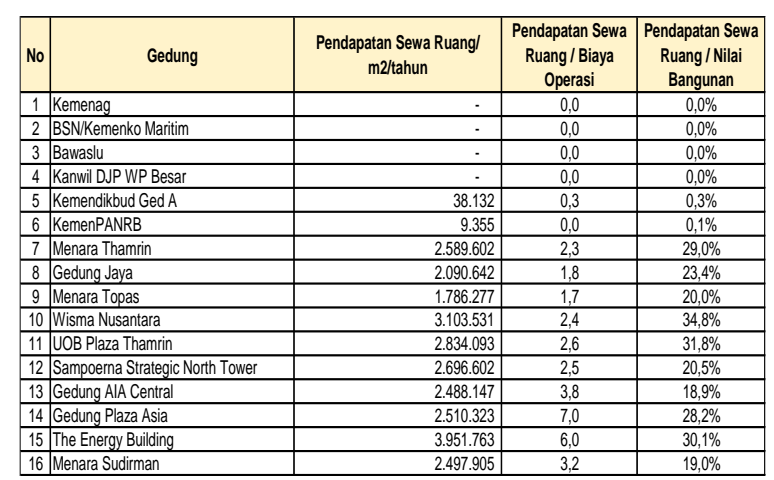

Berdasarkan data sebagaimana tersebut di atas, produktivitas gedung perkantoran milik pemerintah dari sisi finansial jauh tertinggal. Hal tersebut dikarenakan:

a. Pembangunan gedung perkantoran milik pemerintah ditujukan lebih kepada dukungan penyelenggaraan tugas dan fungsi pemerintah, sedangkan gedung perkantoran swasta dibangun dengan tujuan mendapatkan income.

b. Jenis pendapatan yang digunakan dalam menghitung tingkat produktivitas antara gedung pemerintah dengan gedung swasta tidak memenuhi prinsip kesebandingan. Pendapatan gedung perkantoran pemerintah hanya didapatkan dari pemanfaatan sebagian ruangan/gedung yang sedang tidak digunakan untuk mendukung pelaksanaan tugas dan fungsi, sehingga akan diperoleh pendapatan yang jauh lebih kecil. Di sisi lain, pendapatan gedung swasta berasal dari ruangan kantor yang benar-benar ditujukan untuk disewakan dan memiliki proporsi yang dominan terhadap total luas bangunan, sehingga akan menghasilkan total pendapatan yang besar.

c. Biaya operasi yang timbul dari pengelolaan gedung pemerintah lebih kepada mendukung tugas dan fungsi pemerintah. Sedangkan untuk gedung swasta biaya operasi menjadi salah satu variabel yang cukup signifikan untuk diperhitungkan dalam penyediaan layanan gedung.

Dengan demikian, pengukuran tingkat produktivitas hanya dari sisi finansial atas gedung pemerintah kurang tepat digunakan dan tidak dapat dibandingkan dengan gedung kantor swasta.

\subsubsection{Analisis Stakeholder}

Berdasarkan hasil pembahasan pada Poin 2, terlihat bahwa tingkat produktivitas gedung yang memiliki tujuan yang berbeda akan menghasilkan tingkat produktivitas yang jauh berbeda sehingga tidak dapat dijadikan acuan perbandingan produktivitas sebuah gedung. Pendapatan secara finansial yang dihasilkan oleh gedung perkantoran swasta merupakan tujuan dibangunnya gedung tersebut sehingga secara finansial akan 
menghasilkan tingkat produktivitas yang tinggi dan terukur.

Di sisi lain, gedung perkantoran pemerintah dibangun tidak untuk menghasilkan keuntungan finansial (financial benefit) dari keberadaan gedung tersebut melainkan untuk memberikan pelayanan kepada stakeholder serta penyusunan kebijakan. Oleh karena itu, output yang dihasilkan oleh gedung pemerintah tidak dapat serta merta diukur dengan satuan finansial.

Analisis stakeholder ini digunakan untuk memperkirakan benefit nonfinancial dari keberadaan gedung pemerintah khususnya yang terletak di ruas Jalan Thamrin-Sudirman. Analisis stakeholder berdasarkan Project Management Body of Knowledge 5th Edition dilakukan dengan tahapan sebagai berikut:

a. Identifikasi Stakeholder

b. Analisis pengaruh dan kepentingan

c. Identifikasi Partisipasi

Berdasarkan pengamatan yang dilakukan, kawasan Thamrin-Sudirman telah menjadi pusat bisnis di Jakarta maupun di Indonesia oleh karena itu dari 6 (enam) gedung milik Pemerintah yang menjadi objek survei, hanya Kantor Pajak Wajib Pajak Besar yang relevan berada di Jalan Panglima Sudirman guna mendukung fungsi pelayanan terhadap stakeholder di kawasan tersebut.

\subsubsection{Analisis Penggunaan Tertinggi dan Terbaik}

Dengan memperhatikan bahwa dari hasil analisis tingkat produktivitas gedung pemerintahan yang menunjukkan nilai yang rendah maka dalam analisis ini, juga dilakukan Analisis Penggunaan Tertinggi dan terbaik/ Highest and Best Use (HBU).

\subsubsection{Analisis Aspek Legalitas}

a. Analisis Peruntukan Area (Zoning)

Berdasarkan Peraturan Daerah Provinsi

DKI Jakarta nomor 1 Tahun 2014 yang mengatur tentang Rencana Detail Tata Ruang dan Peraturan Zonasi Provinsi DKI Jakarta, objek analisis berupa lahan di Jalan Thamrin milik Kementerian Agama, Badan Penganalisis dan Penerapan Teknologi (BPPT), lahan Jalan Sudirman milik Kementerian Pendayagunaan Aparatur Negara dan Reformasi, Kementerian Pendidikan dan kebudayaan, dan Kanwil Direktorat Jenderal Pajak Wajib Pajak Besar masuk ke dalam Zona Pemerintahan Nasional. Hal ini berarti bahwa untuk kelima objek ini tidak diperbolehkan untuk mengubah penggunaannya selain dari gedung pemerintahan. Oleh karena itu, analisis HBU ini berfokus hanya kepada lahan yang penggunaannya dapat digunakan untuk kegiatan komersil.

Sedangkan lahan milik Sekretariat Negara yang digunakan oleh BAWASLU di Jalan M.H. Thamrin masuk ke dalam Zona Perkantoran, Perdagangan dan Jasa, Sub Zona Perkantoran.
Objek analisis saat ini merupakan tanah dan gedung milik pemerintah pusat yang digunakan sebagai gedung Badan Pengawas Pemilu (BAWASLU). Peletakan gedung BAWASLU yang berada pada Zona Perkantoran, Perdagangan dan Jasa, Sub Zona Perkantoran, diperbolehkan dan diijinkan menurut Peraturan Zonasi yang berlaku dan tidak melanggar peraturan tersebut.

b. Analisis Perizinan Bangunan

Dalam pasal 637 Perda DKI Jakarta Nomor 1 Tahun 2014 disebutkan bahwa setiap orang yang akan melakukan pemanfaatan yang wajib memiliki izin dari Gubernur yang secara operasional menjadi tugas Kepala Satuan Perangkat Kerja Daerah (SKPD) dan/atau instansi terkait sesuai fungsinya.

c. Kesimpulan dari Aspek Legalitas

Dari hasil analisis atas legalitas tersebut, didapat bahwa hanya gedung Bawaslu yang secara legal dapat dikembangkan menjadi bangunan untuk peruntukan yang lain, yaitu gedung perkantoran dan bisnis professional lain, atau dapat pula sebagai perhotelan dan retail (mixed use).

\subsubsection{Analisis Aspek Fisik}

a. Analisis Fisik atas Tanah

Analisis fisik atas tanah dilakukan terhadap :

1) Lokasi

Lokasi objek analisis berada Jalan M.H. Thamrin No. 14, Kelurahan Gondangdia, Kecamatan Menteng, Kota Jakarta Pusat, Provinsi Daerah Khusus Ibukota Jakarta. Dengan luas lahan sesuai sertifikat sebesar $2.020 \mathrm{~m}^{2}$.Objek analisis berada di titik koordinat -6.18757 S, 106.82272 E.

2) Karakteristik Lahan

Objek analisis berbentuk persegi panjang dengan lebar depan yang menghadap jalan, sehingga cocok didirikan bangunan secara proporsional. Topografi dan kontur lahan objek analisis adalah datar dengan elevasi sejajar dengan jalan di depannya. Dimensi lahan dengan panjang $29 \mathrm{~m}$ dan lebar $70 \mathrm{~m}$. Jenis tanah, objek analisis memiliki jenis tanah darat yang telah matang karena saat ini sudah berdiri bangunan kantor di atasnya.

3) Infrastruktur, Utilitas dan Layanan Publik

Fasilitas-fasilitas umum yang terdapat di sekitar objek analisis diantaranya adalah pusat perbelanjaan Sarinah, gedung perkantoran seperti gedung Topaz, kantor perbankan dan ATM BRI, BNI, Panin, Mandiri, BCA, BNI dan BRI, serta gedung hotel Four Points by Sheraton. Layanan transportasi seperti bus kota, taksi maupun bus Transjakarta yang memiliki halte di depan objek analisis.

4) Aksesibilitas

Jalan M.H. Thamrin di depan objek analisis memiliki lebar jalan \pm 40 meter dengan arah lalu lintas dua arah yaitu ke arah Bundaran Hotel Indonesia dan arah Monumen Nasional (Monas). 


\section{b. Analisis Fisik atas Bangunan Existing}

$\mathrm{Di}$ atas lahan objek analisis telah berdiri bangunan berupa gedung kantor 5 lantai dengan kondisi baik namun spesifikasi maupun kualitas material bangunan lebih rendah dibandingkan gedung perkantoran sekitar. Menurut analisis bangunan tersebut perlu dioptimalkan dengan membangun bangunan gedung baru yang lebih baik. Dalam analisis penggunaan tertinggi dan terbaik pada laporan ini karena bangunan yang berdiri di atasnya kurang layak maka tim melakukan analisis terhadap tanah dan bangunan.

\section{c. Analisis Pengembangan Lahan}

Memperhatikan karakteristik penggunaan bangunan di sekitar objek analisis dan kondisi bangunan existing di atas lahan objek analisis maka diperlukan pengembangan lahan dengan alasan sebagai berikut :

$>$ tanah yang tersedia memiliki luas $2.020 \mathrm{~m}^{2}$ dan berada di kawasan bisnis Kota Jakarta Pusat.

$>$ Sesuai dengan peraturan daerah terhadap lahan tersebut masih dapat dikembangkan dengan lebih optimal;

$>$ bangunan existing berupa gedung kantor 5 lantai kurang sesuai dengan bangunan yang ada di sekitar objek analisis berupa bangunan perkantoran dan komersial dengan tinggi lebih dari 5 lantai;

Dengan memperhatikan analisis data dan ukuran lahan pengembangan, maka yang memungkinkan untuk dibangun adalah gedung perkantoran atau perhotelan. Pada analisa fisik ini pengembangan dibatasi pada pembangunan gedung 9 lantai (sesuai peraturan saat ini), 18 lantai (pengembangan dua kali dari batasan peraturan) dan 22 lantai (sesuai maksimal daya dukung tanah). Analisa sebagai berikut:

1) Gedung Perkantoran

a) Pembangunan gedung perkantoran sesuai peraturan zonasi, dapat dibangun gedung sebagai berikut:

- Luas tapak maksimal 939,30 $\mathrm{m}^{2}$

- Ukuran lahan pengembangan $47 \times 20 \mathrm{~m}$

- Luas bangunan maksimal (gross area) $8.665,80 \mathrm{~m}^{2}$

- Jumlah lantai maksimal 9 lantai

- Luas Basement maksimal $517 \mathrm{~m}^{2}$

- Efisiensi luas lantai $88 \%$

- Luas bangunan bersih (semigross area) $7.625,90 \mathrm{~m}^{2}$

- Biayakonstruksi Rp76.182.183.000,00

- Biaya pembongkaran gedung lama Rp1.222.500.000,00 b) Pembangunan gedung perkantoran dua kali dari peraturan zonasi, dapat dibangun gedung sebagai berikut:

- Luas tapak maksimal 939,30 $\mathrm{m}^{2}$

- Ukuran lahan pengembangan $47 \times 20 \mathrm{~m}$

- Luas bangunan maksimal (gross area) $16.907,40 \mathrm{~m}^{2}$

- Jumlah lantai maksimal 18 lantai

- Luas Basement maksimal $517 \mathrm{~m}^{2}$

- Efisiensi luas lantai $88 \%$

- Luas bangunan bersih (semigross area) $14.878,51 \mathrm{~m}^{2}$

- Biaya konstruksi Rp148.635.168.269,00

- Biaya relokasi kantor Bawaslu Rp115.464.623.725,00

- Nilai Kompensasi Rp161.373.986.014,00

- Biaya pembongkaran gedung lama Rp1.222.500.000,00

c) Pembangunan gedung perkantoran sesuai daya dukung tanah, dapat dibangun gedung sebagai berikut:

- Luas tapak maksimal 939,30 $\mathrm{m}^{2}$

- Ukuran lahan pengembangan $47 \times 20 \mathrm{~m}$

- Luas bangunan maksimal (gross area) $20.664,60 \mathrm{~m}^{2}$

- Jumlah lantai maksimal 22 lantai

- Luas Basement maksimal $517 \mathrm{~m}^{2}$

- Efisiensi luas lantai $88 \%$

- Luas bangunan bersih (semigross area) $18.184,85 \mathrm{~m}^{2}$

- Biaya konstruksi Rp181.665.205.663,00

- Biaya relokasi kantor Bawaslu Rp115.464.623.725,00

- Nilai Kompensasi Rp234.941.538.462,00

- Biaya pembongkaran gedung lama Rp1.222.500.000,00

2) Gedung Perhotelan

a) Pembangunan gedung perhotelan maksimal sesuai peraturan zonasi, dapat dibangun gedung sebagai berikut:

- Luas tapak maksimal 939,30 $\mathrm{m}^{2}$

- Ukuran lahan pengembangan $47 \times 20 \mathrm{~m}$

- Luas bangunan maksimal (gross area) $8.665,80 \mathrm{~m}^{2}$

- Jumlah lantai maksimal 9 lantai

- Luas Basement maksimal $517 \mathrm{~m}^{2}$

- Efisiensi luas lantai $75 \%$

- Luas bangunan bersih (semigross area) $6.499,35 \mathrm{~m}^{2}$

- Tipe Hotel Bintang 4 atau Bintang 5

- Jumlah kamar standar (ukuran $24 \mathrm{~m}^{2}$ ) 190 unit

- Jumlah kamar suite (ukuran $\left.48 \mathrm{~m}^{2}\right) 10$ unit

- Ruang pertemuan $939,30 \mathrm{~m}^{2}$ (1 lantai) 
- Ruang komersial dan restoran $939,30 \mathrm{~m}^{2}(1$ lantai)

- Biaya konstruksi Rp120.000.000.000,00

- Biaya pembongkaran gedung lama Rp1.222.500.000,00

b) Pembangunan gedung perhotelan dua kali dari peraturan zonasi, dapat dibangun gedung sebagai berikut:

- Luas tapak maksimal 939,30 $\mathrm{m}^{2}$

- Ukuran lahan pengembangan $47 \times 20 \mathrm{~m}$

- Luas bangunan maksimal (gross area) $16.907,40 \mathrm{~m}^{2}$

- Jumlah lantai maksimal 18 lantai

- Luas Basement maksimal $517 \mathrm{~m}^{2}$

- Efisiensi luas lantai $75 \%$

- Luas bangunan bersih (semigross area) $12.680,55 \mathrm{~m}^{2}$

- $\quad$ Tipe Hotel Bintang 4 atau Bintang 5

- Jumlah kamar standar (ukuran $24 \mathrm{~m}^{2}$ ) 244 unit

- Jumlah kamar suite (ukuran $48 \mathrm{~m}^{2}$ ): 10 unit

- Ruang pertemuan: $1.409 \mathrm{~m}^{2}$ (2lantai)

- Ruang komersial dan restoran: $2.818 \mathrm{~m}^{2}$ (4lantai)

- Parkiran 2.113m² (3lantai)

- Biaya konstruksi: Rp 226.717.584.135,00

- Biaya relokasi kantor Bawaslu Rp115.464.623.725,00

- Nilai kompensasi Rp161.373.986.014,00

- Biaya pembongkaran gedung lama Rp1.222.500.000,00

c) Pembangunan gedung perhotelan sesuai daya dukung tanah, dapat dibangun gedung sebagai berikut:

- $\quad$ Luas tapak maksimal 939,30 $\mathrm{m}^{2}$

- Ukuran lahan pengembangan 47 x $20 \mathrm{~m}$

- Luas bangunan maksimal (gross area) $20.664,60 \mathrm{~m}^{2}$

- Jumlah lantai maksimal 22 lantai

- Luas Basement maksimal $517 \mathrm{~m}^{2}$

- Efisiensi luas lantai $75 \%$

- Luas bangunan bersih (semigross area) $15.498,45 \mathrm{~m}^{2}$

- $\quad$ Tipe Hotel Bintang 4 atau Bintang 5

- Jumlah kamar standar (ukuran $24 \mathrm{~m}^{2}$ ) 302 unit

- Jumlah kamar suite (ukuran $48 \mathrm{~m}^{2}$ ) 10 unit

- Ruang pertemuan $1.409 \mathrm{~m}^{2}$ (2 lantai)

- Ruang komersial dan restoran $2.818 \mathrm{~m}^{2}$ (4lantai)

- Parkiran $3.335 \mathrm{~m}^{2}$ (5 lantai)

- Biaya konstruksi Rp273.810.560.310,00

- Biaya relokasi kantor Bawaslu Rp115.464.623.725,00

- $\quad$ Nilai kompensasi Rp234.941.538.462,00
- Biaya pembongkaran gedung lama Rp1.222.500.000,00

\subsubsection{Analisis Aspek Finansial}

Analisis aspek financial dilakukan terhadap alternatif penggunaan yang memenuhi persyaratan aspek legalitas dan aspek fisik untuk mengetahui kelayakan secara keuangan atas alternatif penggunaan lahan.

a. Analisis Proyeksi Laba Rugi dan Arus Kas

Alternatif 1. Gedung Perkantoran 18 lantai dengan membangun gedung pengganti bagi Bawaslu

1) Analisis Investasi Awal (initial outlay)

Perkiraan total biaya investasi awal pembangunan gedung perkantoran 18 lantai dengan 1 basement, dengan rincian sebagai berikut:

$\begin{array}{llr}1 & \begin{array}{l}\text { Biaya Pembongkaran } \\ \text { Gedung }\end{array} & 1.222 .500 .000 \\ 2 & \begin{array}{l}\text { Biaya Pembangunan } \\ \text { Gedung }\end{array} & 148.635 .168 .269 \\ 3 & \begin{array}{l}\text { Biaya Kompensasi KLB } \\ 4\end{array} & \text { 161.373.986.014 } \\ & \begin{array}{l}\text { Biaya Pembangunan } \\ \text { Gedung Pengganti } \\ \text { Biaya Sewa Kantor } \\ \text { Sementara Bawaslu }\end{array} \\ & \text { 15.517.200.000 } \\ \text { Total } & \mathbf{4 2 6 . 6 9 6 . 2 7 7 . 5 5 8}\end{array}$

2) Analisis Pendapatan

Pendapatan yang diasumsikan dapat diperoleh dari pembangunan gedung perkantoran adalah sebagai berikut:

a) Pendapatan sewa perkantoran

Pedapatan sewa perkantoran didapatkan dengan menggunakan asumsi luas area sewa $14.879 \mathrm{~m}^{2}$, occoupancy rate $65 \%$ - $85 \%$, tarif sewa(2018) Rp280.000,-/m²/bulan, tarif Service Charge(2018) Rp85.000,-/m2/bulan, kenaikan tarif sebesar rata-rata inflasi selama 5 tahun terakhir.

b) Pendapatan Sewa Ruang ATM

Luas area sewa $20 \mathrm{~m}^{2}$, Accoupancy Rate: $50 \%$ $100 \%$, Tarif sewa (2018) Rp300.000,-/ $\mathrm{m}^{2} /$ bulan, Kenaikan tarif sebesar rata-rata inflasi selama 5 tahun terahir

c) Pendapatan Minor Operating Departement (MOD)

Pendapatan ini adalah asumsi pendapatan dari parkir dan denda over time penggunaan ruang kantor, dengan besaran $2 \%$ dari pendapatan sewa kantor.

3) Analisis Beban

a) Beban Pokok Penjualan

Beban pokok penjualan ditetapkan sebesar 85\% dari total Service Charge, didalamnya 
terdapat komponen beban listrik dan pemeliharaan.

b) Beban Operasional

Rincian beban operasional adalah Beban administrasi dan Umum, Beban Gaji, Beban Pemasaran, Beban Asuransi, Beban PBB, Beban Management Fee dan Beban lain-lain

c) Beban Depresiasi

Beban depresiasi bangunan dilakukan dengan metode garis lurus dengan usia ekonomis bangunan adalah 30 tahun.

d) Beban Pajak

Beban pajak yang diperhitungkan disini adalah pajak final untuk sewa sebesar $10 \%$ dari pendapatan.

4) Analisis Capital Expenditures

Untuk menjaga kondisi bangunan agar tetap dapat digunakan secara optimal, di luar kewajiban penyewa, Tim menetapkan perlunya capital expenditures, dengan asumsi sebagai berikut:

a) Capital expenditure dilakukan secara terjadwal selama masa umur ekonomis bangunan.

b) Umur ekonomis bangunan ditetapkan selama 30 tahun.

c) Capital expenditure dijadwalkan setiap 5 tahun.

d) Dibentuk penyisihan dana/reserved fund setiap tahun dengan besaran 3\% dari total pendapatan tahunan. Selanjutnya digunakan sebagai capital expenditure setiap 4 tahun.

Alternatif 2. Gedung Perkantoran 18 lantai dengan mengalokasikan sebagian ruangan pada gedung baru bagi Bawaslu

1) Analisis Investasi Awal (initial outlay)

Perkiraan total biaya investasi awal pembangunan gedung perkantoran 18 lantai dengan 1 basement, dengan rincian sebagai berikut:

1 Biaya Pembongkaran

1.222 .500 .000

Gedung

2 Biaya Pembangunan

148.635.168.269

Gedung

3 Biaya Kompensasi KLB

161.373.986.014

4 Biaya Sewa Kantor

15.517.200.000

Sementara Bawaslu

Total

326.748.854.283

2) Analisis Pendapatan

Pendapatan yang diasumsikan dapat diperoleh dari pembangunan gedung perkantoran adalah sebagai berikut:

a) Pendapatan sewa perkantoran

Pedapatan sewa perkantoran didapatkan dengan menggunakan asumsi Luas area sewa $4.728 \mathrm{~m}^{2}$, Accoupancy Rate 65\% - 85\%, Tarif sewa (2018) Rp280.000,-/ $\mathrm{m}^{2} /$ bulan, Tarif
Service Charge (2018): Rp85.000,-/m2/bulan dan kenaikan tarif sebesar rata-rata inflasi selama 5 tahun terakhir.

b) Pendapatan Sewa Ruang ATM Luas area sewa $20 \mathrm{~m}^{2}$, Accoupancy Rate: 50\% 100\%, Tarif sewa (2018) Rp300.000,-/m²/bulan, Kenaikan tarif sebesar rata-rata inflasi selama 5 tahun terahir.

c) Pendapatan Minor Operating Departement (MOD)

Pendapatan ini adalah asumsi pendapatan dari parkir dan denda over time penggunaan ruang kantor, dengan besaran $2 \%$ dari pendapatan sewa kantor.

3) Analisis Beban

a) Beban Pokok Penjualan

Beban pokok penjualan ditetapkan sebesar 85\% dari total Service Charge, di dalamnya terdapat komponen beban listrik dan pemeliharaan.

b) Beban Operasional

Rincian beban operasional adalah Beban administrasi dan Umum, Beban Gaji, Beban Pemasaran, Beban Asuransi, Beban PBB, Beban Management Fee dan Beban lain-lain.

c) Beban Depresiasi

Beban depresiasi bangunan dilakukan dengan metode garis lurus dengan usia ekonomis bangunan adalah 30 tahun.

d) Beban Pajak

Beban pajak yang diperhitungkan disini adalah pajak final untuk sewa sebesar $10 \%$ dari pendapatan.

4) Analisis Capital Expenditures

Untuk menjaga kondisi bangunan agar tetap dapat digunakan secara optimal, di luar kewajiban penyewa, Tim menetapkan perlunya capital expenditures, dengan asumsi sebagai berikut:

a) Capital expenditure dilakukan secara terjadwal selama masa umur ekonomis bangunan.

b) Umur ekonomis bangunan ditetapkan selama 30 tahun.

c) Capital expenditure dijadwalkan setiap 5 tahun.

d) Dibentuk penyisihan dana/reserved fund setiap tahun dengan besaran $3 \%$ dari total pendapatan tahunan. Selanjutnya digunakan sebagai capital expenditure setiap 4 tahun.

Alternatif 3. Gedung Perkantoran 22 lantai dengan membangun gedung pengganti bagi Bawaslu

1) Analisis Investasi Awal (initial outlay)

Perkiraan total biaya investasi awal pembangunan gedung perkantoran 22 lantai dengan 1 basement, dengan rincian sebagai berikut:

1 Biaya Pembongkaran 1.222.500.000 Gedung 
2

Biaya

Pembangunan

181.665.205.663

Gedung

3

Biaya Kompensasi KLB

234.941.538.462

4 Biaya Pembangunan

99.947 .423 .275

Gedung Pengganti

5 Biaya Sewa Kantor

Sementara Bawaslu

Total

533.293.867.399

2) Analisis Pendapatan

Pendapatan yang diasumsikan dapat diperoleh dari pembangunan gedung perkantoran adalah sebagai berikut:

a) Pendapatan sewa perkantoran

Pedapatan sewa perkantoran didapatkan dengan menggunakan asumsi Luas area sewa $15.197 \mathrm{~m}^{2}$, Accoupancy Rate 65\% - 85\%, Tarif sewa (2018) Rp280.000,-/ $\mathrm{m}^{2} /$ bulan, Tarif Service Charge (2018) Rp85.000,-/m2/bulan, Kenaikan tarif sebesar rata-rata inflasi selama 5 tahun terakhir.

b) Pendapatan Sewa Ruang ATM

Luas area sewa $20 \mathrm{~m}^{2}$, Accoupancy Rate: $50 \%$ 100\%, Tarif sewa (2018) Rp300.000,-/ $\mathrm{m}^{2} /$ bulan, Kenaikan tarif sebesar rata-rata inflasi selama 5 tahun terahir.

c) Pendapatan Minor Operating Departement (MOD)

Pendapatan ini adalah asumsi pendapatan dari parkir dan denda over time penggunaan ruang kantor, dengan besaran $2 \%$ dari pendapatan sewa kantor.

3) Analisis Beban

a) Beban Pokok Penjualan

Beban pokok penjualan ditetapkan sebesar 85\% dari total Service Charge, di dalamnya terdapat komponen beban listrik dan pemeliharaan.

b) Beban Operasional

Rincian beban operasional adalah Beban administrasi dan Umum, Beban Gaji, Beban Pemasaran, Beban Asuransi, Beban PBB, Beban Management Fee dan Beban lain-lain.

c) Beban Depresiasi

Beban depresiasi bangunan dilakukan dengan metode garis lurus dengan usia ekonomis bangunan adalah 30 tahun.

d) Beban Pajak

Beban pajak yang diperhitungkan disini adalah pajak final untuk sewa sebesar $10 \%$ dari pendapatan.

4) Analisis Capital Expenditures

Untuk menjaga kondisi bangunan agar tetap dapat digunakan secara optimal, di luar kewajiban penyewa, Tim menetapkan perlunya capital expenditures, dengan asumsi sebagai berikut: a) Capital expenditure dilakukan secara terjadwal selama masa umur ekonomis bangunan.

b) Umur ekonomis bangunan ditetapkan selama 30 tahun.

c) Capital expenditure dijadwalkan setiap 5 tahun.

d) Dibentuk penyisihan dana/reserved fund setiap tahun dengan besaran 3\% dari total pendapatan tahunan. Selanjutnya digunakan sebagai capital expenditure setiap 4 tahun.

Alternatif 4. Gedung Perkantoran 22 lantai dengan mengalokasikan sebagian ruangan pada gedung baru bagi Bawaslu

1) Analisis Investasi Awal (initial outlay)

Perkiraan total biaya investasi awal pembangunan gedung perkantoran 22 lantai dengan 1 basement, dengan rincian sebagai berikut:

$\begin{array}{llr}1 & \begin{array}{l}\text { Biaya Pembongkaran } \\ \text { Gedung } \\ 2\end{array} & \text { 1.222.500.000 } \\ & \begin{array}{l}\text { Biaya Pembangunan } \\ \text { Gedung } \\ \text { Biaya Kompensasi KLB }\end{array} & \text { 234.941.538.462 } \\ 3 & \begin{array}{l}\text { Biaya Sewa Kantor } \\ \text { Sementara Bawaslu } \\ \text { Total }\end{array} & \mathbf{1 5 . 5 1 7 . 2 0 0 . 0 0 0} \\ & \mathbf{4 3 3 . 3 4 6 . 4 4 4 . 1 2 5}\end{array}$

2) Analisis Pendapatan

Pendapatan yang diasumsikan dapat diperoleh dari pembangunan gedung perkantoran adalah sebagai berikut:

a) Pendapatan sewa perkantoran

Pedapatan sewa perkantoran didapatkan dengan menggunakan asumsi Luas area sewa $5.046 \mathrm{~m}^{2}$, Accoupancy Rate: 65\% - 85\%, Tarif sewa (2018) Rp280.000,-/ $\mathrm{m}^{2} /$ bulan, Tarif Service Charge (2018: Rp85.000,-/m2/bulan, Kenaikan tarif sebesar rata-rata inflasi selama 5 tahun terakhir.

b) Pendapatan Sewa Ruang ATM Luas area sewa $20 \mathrm{~m}^{2}$, Accoupancy Rate: 50\% 100\%, Tarif sewa (2018) Rp300.000,-/m²/bulan, Kenaikan tarif sebesar rata-rata inflasi selama 5 tahun terahir.

c) Pendapatan Minor Operating Departement (MOD)

Pendapatan ini adalah asumsi pendapatan dari parkir dan denda over time penggunaan ruang kantor, dengan besaran $2 \%$ dari pendapatan sewa kantor.

3) Analisis Beban

a) Beban Pokok Penjualan Beban pokok penjualan ditetapkan sebesar $85 \%$ dari total Service Charge, di dalamnya terdapat komponen beban listrik dan pemeliharaan.

b) Beban Operasional 
Rincian beban operasional adalah Beban administrasi dan Umum, Beban Gaji, Beban Pemasaran, Beban Asuransi, Beban PBB, Beban Management Fee dan beban lain-lain.

c) Beban Depresiasi

Beban depresiasi bangunan dilakukan dengan metode garis lurus dengan usia ekonomis bangunan adalah 30 tahun.

d) Beban Pajak

Beban pajak yang diperhitungkan disini adalah pajak final untuk sewa sebesar $10 \%$ dari pendapatan.

4) Analisis Capital Expenditures

Untuk menjaga kondisi bangunan agar tetap dapat digunakan secara optimal, di luar kewajiban penyewa, Tim menetapkan perlunya capital expenditures, dengan asumsi sebagai berikut:

a) Capital expenditure dilakukan secara terjadwal selama masa umur ekonomis bangunan.

b) Umur ekonomis bangunan ditetapkan selama 30 tahun.

c) Capital expenditure dijadwalkan setiap 5 tahun.

d) Dibentuk penyisihan dana/reserved fund setiap tahun dengan besaran 3\% dari total pendapatan tahunan. Selanjutnya digunakan sebagai capital expenditure setiap 4 tahun.

Alternatif 5. Dibangun Bangunan Hotel dan Retail (mixed use) 18 lantai dengan membangun gedung pengganti bagi Bawaslu.

1) Analisis Investasi Awal (initial Outlay)

Perkiraan total biaya investasi awal pembangunan Bangunan 18 lantai dengan 1 basement yang akan dipergunakan untuk hotel dan retail adalah sebagai berikut:
1 Biaya
Pembongkaran
1.222 .500 .000
Gedung
2 Biaya
Pembangunan
226.717.584.135
Gedung
3 Biaya Kompensasi KLB
161.373.986.014
4 Biaya Pembangunan
99.947 .423 .275
Gedung Pengganti
5 Biaya Sewa Kantor
Sementara Bawaslu
Total
15.517.200.000
504.778.693.424

\section{2) Analisis Pendapatan}

Pendapatan yang diasumsikan dapat diperoleh dari pembangunan gedung hotel dan retail yaitu:

a) Pendapatan jasa kamar perhotelan

Hotel yang diasumsikan akan dibangun adalah hotel berbintang 4, sehingga tarif dan beban akan menyesuaikan standart hotel bintang 4. Berikut asumsi komponen pendapatan jasa kamar hotel. Jumlah kamar standar 244 kamar, Jumlah kamar suite 10 kamar, Accoupancy Rate 40\%-60\%, Tarif kamar standar (2020) Rp1.270.000,-/malam, Tarif service charge (2020) Rp2.415.000,-/malam, Kenaikan tarif sebesar rata-rata inflasi 5 tahun terahir.

b) Pendapatan jasa ruang pertemuan

Dalam hotel juga diasumsikan terdapat ruang pertemuan berupa ballroom dan ruang rapat. Berikut asumsi komponen pendapatan jasa ruang rapat

Jumlah ruang pertemuan:

\begin{tabular}{clcc} 
No & $\begin{array}{c}\text { Ruang } \\
\text { Pertemuan }\end{array}$ & Kapasitas & $\begin{array}{c}\text { Jumlah } \\
\text { ruang }\end{array}$ \\
\hline 1. & Ball Room & 300 & 1 \\
2. & 1/3 Ballroom & 100 & 3 \\
3. & Meeting small & 50 & 2 \\
4. & Meeting small & 75 & 2
\end{tabular}

Tarif Wedding Rp653.000/paxx, Tarif Meeting Rp526.500/paxx, Accoupancy rate: 40\%-60\%, Kenaikan tarif sebesar rata-rata inflasi 5 tahun terahir.

c) Pendapatan sewa retail

Pendapatan sewa retail diperoleh dengan asumsi Luas area sewa 2.817,9 $\mathrm{m}^{2}$, Accoupancy Rate 60\% - 90\%, Tarif sewa (2018) Rp545.000,$/ \mathrm{m}^{2} /$ bulan, Tarif Service Charge (2018) Rp131.000,-/m2/bulan, Kenaikan tarif sebesar rata-rata inflasi selama 5 tahun terahir.

3) Analisis Beban, terdiri dari:

a) Beban pokok penjualan Hotel

b) Beban pokok penjualan Sewa Retail

Beban OperasionalAdministrasi and general, Marketing, Property Operational Management Energy Cost (POMEC), Assuransi gedung, PBB dan Beban lain-lain.

c) Beban Depresiasi

Beban depresiasi bangunan dilakukan dengan metode garis lurus dengan usia ekonomis bangunan adalah 30 tahun.

d) Beban Pajak

Beban pajak diasumsikan sebesar 20\% dari EBT.

4) Analisis Capital Expenditures

Untuk menjaga kondisi bangunan agar tetap dapat digunakan secara optimal, di luar kewajiban penyewa, Tim menetapkan perlunya capital expenditures, dengan asumsi sebagai berikut:

a) Capital expenditure dilakukan secara terjadwal selama masa umur ekonomis bangunan.

b) Umur ekonomis bangunan ditetapkan selama 40 tahun. 
c) Capital expenditure dijadwalkan setiap 5 tahun.

d) Dibentuk penyisihan dana/reserved fund setiap tahun dengan besaran $2 \%$ dari total pendapatan tahunan. Selanjutnya digunakan sebagai capital expenditure setiap 5 tahun.

Alternatif 6. dibangun Bangunan Hotel dan Retail (mixed use) 22 lantai dengan membangun gedung pengganti bagi Bawaslu.

1) Analisis Investasi Awal (initial Outlay)

Perkiraan total biaya investasi awal pembangunan Bangunan 22 lantai dengan 1 basement yang akan dipergunakan untuk hotel dan retail adalah sebagai berikut:

$\begin{array}{llr}1 & \begin{array}{l}\text { Biaya Pembongkaran } \\ \text { Gedung }\end{array} & 1.222 .500 .000 \\ 2 & \begin{array}{l}\text { Biaya Pembangunan } \\ \text { Gedung }\end{array} & \text { 273.810.560.310 } \\ 3 & \begin{array}{l}\text { Biaya Kompensasi KLB } \\ \text { 234.941.538.462 }\end{array} \\ 4 & \begin{array}{l}\text { Biaya Pembangunan } \\ \text { Gedung Pengganti }\end{array} & \text { 99.947.423.275 } \\ 5 & \begin{array}{l}\text { Biaya Sewa Kantor } \\ \text { Sementara Bawaslu } \\ \text { Total }\end{array} & \mathbf{6 2 5 . 4 3 9 . 2 2 2 . 0 4 7}\end{array}$

2) Analisis Pendapatan

Pendapatan yang diasumsikan dapat diperoleh dari pembangunan gedung hotel dan retail yaitu:

a) Pendapatan jasa kamar perhotelan Hotel yang diasumsikan akan dibangun adalah hotel berbintang 4, sehingga tarif dan beban akan menyesuaikan standart hotel bintang 4. Berikut asumsi komponen pendapatan jasa kamar hotel. Jumlah kamar standar 302 kamar, Jumlah kamar suite 10 kamar, Accoupancy Rate 40\% - 60\%, Tarif kamar standar (2020) Rp1.270.000,-/malam, Tarif service charge (2020) Rp2.415.000,-/malam, Kenaikan tarif sebesar rata-rata inflasi 5 tahun terahir.

b) Pendapatan jasa ruang pertemuan

Dalam hotel juga diasumsikan terdapat ruang pertemuan berupa ballroom dan ruang rapat. Berikut asumsi komponen pendapatan jasa ruang rapat. Jumlah ruang meeting :

$\begin{array}{clcc}\text { No } & \text { Ruang Meeting } & \text { Kapasitas } & \begin{array}{c}\text { Jumlah } \\ \text { ruang }\end{array} \\ \text { 1. } & \text { Ball Room } & 300 & 1 \\ \text { 2. } & \text { 1/3 Ballroom } & 100 & 3 \\ \text { 3. } & \text { Meeting small } & 50 & 2 \\ \text { 4. } & \text { Meeting small } & 75 & 2\end{array}$

Tarif Wedding: Rp653.000/paxx, Tarif Meeting: Rp526.500/paxx, Accoupancy rate 40\%-60\%, Kenaikan tarif sebesar rata-rata inflasi 5 tahun terahir.

c) Pendapatan sewa retail

Pendapatan sewa retail diperoleh dengan asumsi Luas area sewa 2.817,9 $\mathrm{m}^{2}$, Accoupancy Rate 60\% - 90\%, Tarif sewa (2018): Rp545.000,$/ \mathrm{m}^{2} /$ bulan, Tarif Service Charge (2018): Rp131.000,-/m2/bulan, Kenaikan tarif: Sebesar rata-rata inflasi selama 5 tahun terahir.

3) Analisis Beban

Beban terdiri dari:

a) Beban pokok penjualan Hotel

b) Beban pokok penjualanSewaRetail

c) Beban Operasional

Administrasi and general, Marketing, Property Operational Management Energy Cost (POMEC), Assuransi gedung, PBB dan Beban lain-lain

d) Beban Depresiasi

Beban depresiasi bangunan dilakukan dengan metode garis lurus dengan usia ekonomis bangunan adalah 30 tahun.

e) Beban Pajak Beban pajak diasumsikan sebesar $20 \%$ dari EBT.

4) Analisis Capital Expenditures

Untuk menjaga kondisi bangunan agar tetap dapat digunakan secara optimal, di luar kewajiban penyewa, di tetapkan perlunya capital expenditures, dengan asumsi sebagai berikut:

a) Capital expenditure dilakukan secara terjadwal selama masa umur ekonomis bangunan.

b) Umur ekonomis bangunan ditetapkan selama 40 tahun.

c) Capital expenditure dijadwalkan setiap 5 tahun.

d) Dibentuk penyisihan dana/reserved fund setiap tahun dengan besaran $2 \%$ dari total pendapatan tahunan. Selanjutnya digunakan sebagai capital expenditure setiap 5 tahun.

\subsubsection{Analisa Kelayakan Proyek}

Analisis kelayakan proyek disusun berdasarkan proyeksi laba rugi dan arus kas. Berdasarkan proyeksi laba rugi dan arus kas atas alternatif pemanfaatan objek analisis diperoleh kesimpulan sebagai berikut:

$\begin{array}{llll}\text { Indikator Kelayakan NPV (Ribu) } & \text { IRR } & \text { PP } & \text { Ket }\end{array}$

Alternatif

1. Gedung Perkantoran

18 lantai + gedung

pengganti bagi

Bawaslu

2. Gedung Perkantoran

18 lantai + alokasi

sebagian ruangan

pada gedung baru

bagi Bawaslu

3. Gedung Perkantoran

22 lantai dengan membangun gedung

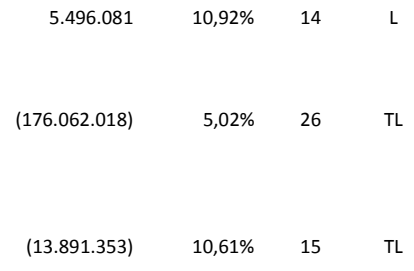




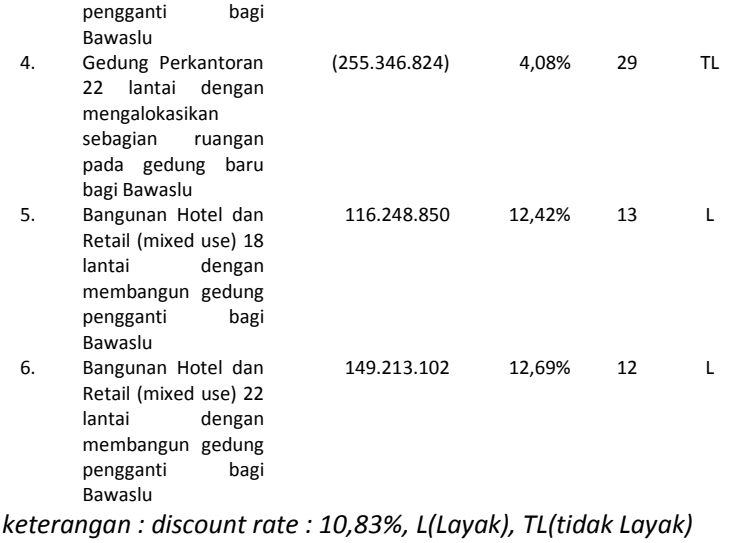

Berdasarkan indikator kelayakan proyek dari 6 alternatif penggunaan tersebut di atas, maka alternatif pengembangan lahan yang dinyatakan lulus uji finansial adalah alternatif yang menghasilkan nilai NPV positif, memiliki tingkat IRR yang melebihi tingkat diskonto, dan Payback Period yang wajar. Alternatif yang lulus uji finansial adalah:

1. Gedung Perkantoran 18 lantai dengan membangun gedung pengganti bagi Bawaslu.

2. Bangunan Hotel dan Retail (mixed use) 18 lantai dengan membangun gedung pengganti bagi Bawaslu.

3. Bangunan Hotel dan Retail (mixed use) 22 lantai dengan membangun gedung pengganti bagi Bawaslu.

\subsubsection{Analisis Aspek Produktifitas Maksimal}

Analisis aspek produktivitas maksimal dilakukan dengan analisis terhadap alternatif penggunaan yang memenuhi persyaratan aspek legalitas, aspek fisik, dan aspek keuangan untuk mengetahui alternatif penggunaan yang menghasilkan produktivitas maksimal. Analisis produktivitas maksimal dilakukan untuk menentukan alternatif penggunaan yang akan memberikan nilai tanah tertinggi.

Berdasarkan analisis data yang dilakukan, diperoleh kesimpulan sebagai berikut:

\begin{tabular}{|l|c|c|c|}
\hline $\begin{array}{c}\text { INDIKATOR } \\
\text { KELAYAKAN }\end{array}$ & $\begin{array}{c}\text { Gedung } \\
\text { Perkantoran 18 } \\
\text { lantai }\end{array}$ & $\begin{array}{c}\text { Bangunan Hotel } \\
\text { dan Retail (mixed } \\
\text { use) 18 lantai }\end{array}$ & $\begin{array}{c}\text { Bangunan Hotel } \\
\text { dan Retail (mixed } \\
\text { use) 22 lantai }\end{array}$ \\
\hline NPV & Rp5.496.081.568 & Rp116.248.850.519 & Rp149.213.102.744 \\
\hline IRR & $10,92 \%$ & $12,42 \%$ & $12,69 \%$ \\
\hline PP & 14 & 13 & 12 \\
\hline
\end{tabular}

Dengan memperhatikan tiga alternatif di atas, didapat bahwa pengembangan lahan menjadi bangunan berupa hotel dan retail (Mixed-Use) 22 lantai akan menghasilkan produktivitas maksimal dibandingkan dengan alternatif pengembangan lainnya.

\section{KESIMPULAN DAN SARAN}

\subsection{Kesimpulan}

Berdasarkan hasil survei yang dilakukan terhadap gedung-gedung perkantoran yang berada di kawasan bisnis sepanjang ruas Jalan $\mathrm{MH}$. Thamrin hingga Jalan Jenderal Sudirman, Jakarta, diperoleh hasil berikut:

a. Berdasarkan analisis produktivitas didapat bahwa gedung perkantoran swasta secara finansial memiliki tingkat produktivitas yang jauh lebih tinggi dibandingkan dengan gedung perkantoran yang dimiliki oleh pemerintah.

b. Berdasarkan analisis stakeholder ditemukan bahwa gedung perkantoran pemerintah yang saat ini berada pada kawasan bisnis tersebut tidak semuanya memiliki fungsi pelayanan terhadap stakeholder yang berada di kawasan tersebut.

c. Berdasarkan analisis HBU didapat hasil bahwa Pengembangan tertinggi dan terbaik atas lahan pemerintah yang berada di Jalan $\mathrm{MH}$ Thamrin adalah dikembangkan sebagai gedung mixused berupa hotel pertokoan retail 22 lantai.

5.2 Saran

a. Bangunan perkantoran pemerintah yang dibangun di kawasan pusat bisnis hendaknya memperhatikan fungsi pelayanan terhadap stakeholder yang berada di pusat bisnis tersebut.

b. Pengembangan atas Barang Milik Negara berupa tanah/tanah berikut bangunan hendaknya didahului dengan pelaksanaan analisis HBU guna mengetahui pengembangan terbaik yang dapat menghasilkan tingkat produktivitas yang maksimal.

c. Untuk dapat menggubah penggunaan lahan kantor pemerintahan di lokasi premium dan strategis, perlu dipertimbangkan mengusulkan perubahan zoning pada lahan dimaksud kepada pihak yang berwenang.

\section{IMPLIKASI DAN KETERBATASAN}

Kajian ini dibuat sesuai dengan ruang lingkup pembahasan dengan batasan seperti pada beberapa hal sebagai berikut:

a. Survei untuk gedung milik swasta hanya terbatas pada 10 (sepuluh) gedung.

b. Survei untuk gedung milik pemerintah untuk 6 (enam) gedung yaitu Gedung Kanwil DJP Wajib Pajak Besar, Gedung A KementerianPendidikan dan Kebudayaan, Gedung Kemenpan RB di Jalan Sudirman. Kemudian gedung Kemenag, Gedung Sekretariat Negara Rlyang digunakan oleh Bawaslu sekarang, dan Gedung BPPT yang digunakan oleh Kemenko Maritim dan Badan Standardisasi Nasional (BSN) di Jalan Thamrin Jakarta. 
c. Analisis yang dibuat terbatas pada 3 (tiga) analisis yang dimaksud dalam ruang lingkup di atas.

d. Pendapatan dari gedung hanya terbatas pada pendapatan sewa ruang saja.

Analisis yang dilakukan dalam laporan ini adalah sebagaimana yang dibahas dalam landasan teori yaitu analisis produktivitas gedung, analisis pemangku kepentingan (stakeholder), dan analisis penggunaan tertinggi dan terbaik (highest and best use/ HBU).

Analisis produktivitas dibuat untuk mengetahui penghasilan properti dibandingkan dengan biaya yang dikeluarkan dalam mengoperasionalkan suatu gedung baik milik swasta maupun milik pemerintah. Kemudian analisis stakeholder dilakukan untuk mengetahui kesesuaian lokasi gedung milik pemerintah dengan pemangku kepentingan dari instansi pengguna gedung tersebut sesuai dengan tugas fungsi yang dimiliki instansi tersebut. Selain itu, analisis HBU untuk salah satu gedung milik pemerintah sebagai alternatif penggunaan lahan dalam upaya untuk memaksimalkan pendapatan atas kepemilikan suatu properti.

\section{PENGHARGAAN}

Penulis menyampaikan terimakasih kepada Bapak Meirijal Nur, Mohamad Nahdi, Ferda Hermanto, Indah Noviana, Mela Laras Mustika dan seluruh anggota Tim pada Subdit SPBSDA, Direktorat Penilaian, DJKN, Kementerian Keuangan.

\section{DAFTAR PUSTAKA}

Anonim. 2011. A Guide to Integrated Management of Productivity Activities (IMPACT). SPRING Singapore.

Anonim. Project Management Body Of Knowledge 5th Edition. ISBN: 978-1-935589-67-9 Published by: Project Management Institute, Inc. 14 Campus Boulevard, Newtown Square, Pennsylvania 19073-3299 USA

Freeman, R. E., (1984). Strategic Management: A Stakeholder Approach. Boston: Pitman Publishing. Darden Graduate School of Business Administration University of Virginia

Ghozali, Imam dan Anis Chariri. 2007. Teori Akuntansi. Semarang: Badan Penerbit Universitas Diponegoro.

Yosevita, Latupapua. 2015. “Implementasi Peran Stakeholder dalam Pengembangan Ekowisata di Taman Nasional Manusela (TNM) di Kabupaten Maluku Tengah." Jurnal Agroforestri X Nomor 1 ISSN : 1907-7556.

Nugroho, Hermawan Cahyo; Soesilo Zauhar; dan Suryadi. (2014) Koordinasi Pelaksanaan
Program Pengembangan Kawasan Agropolitan di Kabupaten Nganjuk. Jurnal JPAL, 5(1) 12-22,

Umar, Husein, 2002, Riset Pemasaran dan Perilaku Konsumen, Penerbit PT. Gramedia Pustaka Utama, Jakarta

Reed, M.S, Graves, A., Dandy, N., Posthumus, H., Hubacek, K., Morris, J., Prell, C., Quinn, C.H., and Stringer, L.C. (2009). Who's In And Why? A Typology Of Stakeholder Analysis Methods For Natural Resource Management. Journal of Environmental Management, 90, 19331949

Sarjono, Haryadi. 2001. Model Pengukuran Produktivitas Berdasarkan Pendekatan Rasio Output Per Input. Fakultas Ekonomi, UBiNus, Jakarta. Journal The WINNERS, Vol. 2 No. 2, September 2001: 130-136

Republik Indonesia. 2014. Peraturan Pemerintah No 27 tentang Pengelolaan Barang Milik Negara/ Daerah

2009. Peraturan Presiden Republik Indonesia Nomor 47 tentang Pembentukan dan Organisasi Kementerian Negara

2017. Peraturan Menteri Keuangan Nomor 210 Tentang Organisasi dan Tata Kerja Instansi Vertikal Direktorat Jenderal Pajak

2015. Peraturan Menteri Pendidikan Dan Kebudayaan Republik Indonesia Nomor 11 Tentang Organisasi dan Tata Kerja Kementerian Pendidikan dan Kebudayaan 2017. Peraturan Menteri PANRB Nomor 12 tentang Perubahan Atas Permen PANRB Nomor 3 Tahun 2016 Tentang Organisasi Dan Tata Kerja Kementerian Pendayagunaan Aparatur Negara Dan Reformasi Birokrasi 2015. Peraturan Kepala BPPT Nomor 9 Tentang Organisasi dan Tata Kerja Badan Penganalisis Dan Penerapan Teknologi

. 2015. Peraturan Menteri Sekretaris Negara Republik Indonesia Nomor 3 Tentang Organisasi Dan Tata Kerja Kementerian Sekretariat Negara

2016. Peraturan Menteri Agama Nomor 42 mengenai Organisasi dan tata Kerja Kementerian Agama

. 2013. Keputusan Direkur Jenderal Kekayaan Negara No.184 tentang Pedoman Analisis Pengunaan Tertinggi dan Terbaik Berupa Tanah atau Tanah Berikut Bangunan 2014. Peraturan Daerah Provinsi Daerah Khusus Ibukota Jakarta Nomor 1 Tentang Rencana Detail Tata Ruang Dan Peraturan Zonasi 
2012. Peraturan Daerah Provinsi Daerah Khusus Ibukota Jakarta Nomor 1 Tentang Rencana Tata Ruang Wilayah 2030
2010. Peraturan Daerah Nomor 7 tentang Bangunan Gedung 